\title{
Geochemistry, metamorphic evolution and tectonic significance of metabasites from Caçapava do Sul, southern Brazil
}

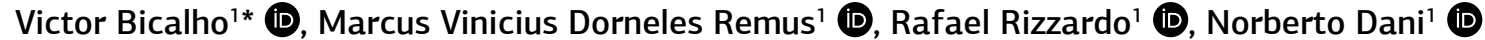

\begin{abstract}
This paper proposes the generation and closure of a proto-ocean and formation of an island arc in the Neoproterozoic Passo Feio Metamorphic Complex (PFMC), Caçapava do Sul region, southern Brazil. The PFMC, São Gabriel Terrane, consists of a Neoproterozoic supracrustal metavolcano-sedimentary sequence intruded by the Caçapava Granite. The study uses petrography, whole-rock geochemistry and mineral chemistry to identify the geochemical affinity and tectonic environment of the amphibolites contained in PFMC, the basalts and pillow lavas of Arroio Mudador Formation and dikes intruded in nearby volcanogenic rocks of Hilário Formation. The applied methods allow the metamorphic facies classification of prehnite-pumpellyite for the basalts and pillow lavas, greenschist for the dikes and lower amphibolite for the amphibolites. The discriminant diagrams indicate from tholeiitic to alkaline affinities for the Hilário Formation dikes. The basalts, pillow lavas and amphibolites have basaltic to basaltic-andesite composition and predominant tholeiitic affinity, interpreted as derived of the same protolith. The geotectonic diagrams mostly indicate volcanic arc basalts. The proposed evolution model starts with a proto-ocean opening through the Bossoroca Arc rifting around 760Ma, where an island arc is formed (PFMC rocks), precipitation of carbonates and marls, subsequent closure, two metamorphism events and the Caçapava Granite intrusion around $562 \mathrm{Ma}$.
\end{abstract}

KEYWORDS: Metabasites; Passo Feio Complex; geochemistry; petrography; metamorphic evolution.

\section{INTRODUCTION}

Metabasites are rocks that register with relative precision the conditions of metamorphism of metamorphic belts, which occur in the most diversified geotectonic environments of the planet from the Archaean to the Phanerozoic. The chemical composition of the major and trace elements of the metabasites, combined with the magmatic pyroxene composition of the protolith and the field petrotectonic association, allows for the identification of the geochemical affinity - magmatic series — and the possible geotectonic environments of their formation (Leterrier $\mathrm{et} \mathrm{al}$. 1982, Morris 1988, Floyd et al. 2000, Maniesi \& Oliveira 2000, $\mathrm{Xu}$ et al. 2008, Faleiros et al. 2011). This paper focuses on the metabasites related to the Passo Feio Metamorphic Complex, São Gabriel Terrane, located in the Caçapava do Sul region in southern Brazil. This metamorphic complex is composed of a

\footnotetext{
Supplementary material

Supplementary data associated with this article can be found in the online version: Supplementary Table 1, Supplementary Table 2, Supplementary Table 3, Supplementary Table 4, Supplementary Table 5 , Supplementary Table 6, Supplementary Table 7, Supplementary Table 8 and Supplementary Figure 1.

${ }^{1}$ Universidade Federal do Rio Grande do Sul - Porto Alegre (RS), Brazil. E-mails: bs.victor@gmail.com, marcus.remus@ufrgs.br, rafaelrizzardo@yahoo.com.br, norberto.dani@ufrgs.br

${ }^{*}$ Corresponding author.
}

C) 2019 The autors. This is an open access article distributed under the terms of the Creative Commons license. neoproterozoic metavolcano-sedimentary sequence intruded by Caçapava Granite about $562 \mathrm{Ma}$ (Remus et al. 2000). An important part of this sequence is composed of metabasic rocks, whose nature and origin are investigated in this paper.

The mafic ortho-derived rocks of the Passo Feio Complex do not have a clear origin in terms of the protolith formation and tectonic environment, so new studies to determine their origin and evolution are required, which may help in understanding the evolution of the São Gabriel Terrane as a whole.

Several studies were conducted in the supracrustal sequence related to the Passo Feio unit (Ribeiro et al. 1966, Ribeiro 1970, Macedo et al. 1978, Bitencourt \& Hartmann 1984a), yet no one agrees on the origin of this sequence. Several authors proposed different geotectonic environments for its origin and evolution: Jost (1966), Szubert et al. (1977) and Fragoso Cesar (1991) classify it as ophiolites (oceanic lithosphere nappes tectonically imbricated in the continental areas). Otherwise, Jost \& Hartmann (1984), Bitencourt \& Hartmann (1984a, 1984b), Remus et al. (1993), Remus et al. (1999) and Hartmann \& Remus (2000) classify it as greenstone belts, referring to the granite-gneiss rocks as granite-greenstone terranes of the Pre-Cambrian age.

This paper consists of a petrologic study of the metabasites using petrography, whole-rock chemical composition and mineral chemistry by microprobe. It is intended to classify and identify the geochemical affinity and tectonic environment of the generation of amphibolites in the metavolcano-sedimentary sequence of the Passo Feio Metamorphic Complex and its comparison with basalts and pillow lavas of the Arroio 
Mudador Formation. Intermediate, basic and ultrabasic dikes intruded in volcanogenic rocks in the Hilário Formation are also studied in this paper to investigate a possibility of a correlation with the previously cited rocks. The study of epidote, chlorite, plagioclase and pyroxene and the compositional zoning of the amphibole allows for the evaluation and proposal of a metamorphic evolution for these metabasic rocks. Bringing all this information together enables the proposal of an evolution and geotectonic environment formation model of the Passo Feio Complex metabasites and associated rocks, involving the opening and closing of a proto-ocean and volcanic arc generation, ending with a continental collision and Caçapava Granite intrusion.

\section{GEOLOGICAL SETTING}

The Sul-Riograndense Shield (SRS), found in the southern part of the Mantiqueira Province (Almeida 1977), consists of an assemblage of rocks formed from the Archaean to the Neoproterozoic, in which the largest accretion occurred in the Transamazonian and the Brasiliano orogenic cycles. The SRS was formed through the agglutination of microcontinents and oceanic island arcs on an old continent, currently the Rio de la Plata Craton (Chemale Jr. 2000, Hartmann et al. 2007). The São Gabriel block or terrane, located in the western part of the SRS, is composed of juvenile calc-alkaline gneisses and metagranitoids, in addition to a metavolcano-sedimentary sequence (Fig. 1) (Jost \& Hartmann 1984, Babinski et al. 1996, Remus et al.2000, Saalmann et al. 2005, Hartmann et al. 2007, Saalmann et al.2010).

The Passo Feio Metamorphic Complex (PFMC) consists of metapelites, amphibolites, amphibole schists, metagabbros and acid to intermediate metavolcanoclastic associations, with occurrences of magnesian schists, marble lenses and tholeiitic basalts with pillow lava structures (Fig. 2). The PFMC has a neoproterozoic age and was derived from several continental sources, as shown through the evidence of zircon xenocrysts with archaean, paleoproterozoic and neoproterozoic ages (Remus et al. 2000, Lopes et al. 2015). The first metamorphism (M1) in the Complex occurred around $700 \mathrm{Ma}$, with a second event (M2) contemporaneous to the Caçapava Granite intrusion, dated at $562 \pm 8 \mathrm{Ma}$ (Remus et al. 2000). Yet, Soliani Jr. (1986) indicates M1 with an age of 660 to $590 \mathrm{Ma}$ (K-Ar method) related to the temperature of the essential mineral closure of intruded diorites and basalts, indicating a crystallization age younger than that age, but there is no consensus of the M1 age.

The metasedimentary rocks consist mainly of an areno-pelitic carbonated sequence, probably deposited through turbidity currents (Remus et al. 1991). The mafic ortho-derived rocks have a volcanogenic origin, and tholeiitic and alkaline geochemical affinity suggests a distensive environment in a continental rift (Hartmann \& Remus 2000).

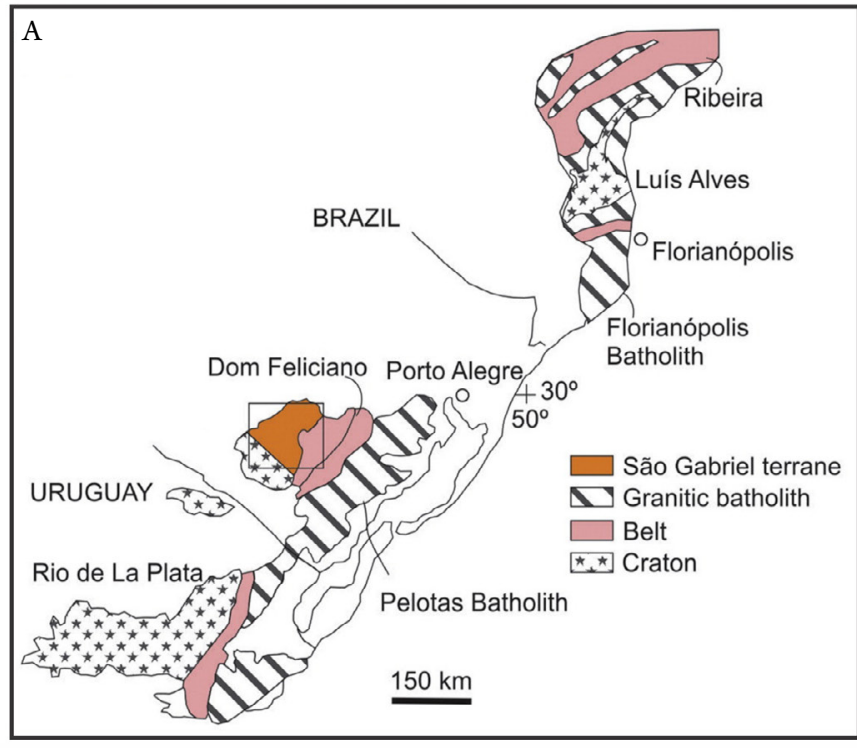

\section{Figure B Legend}

Phanerozoic cover

Camaquã basin

\section{São Gabriel Terrane}

Mafic volcanoclastic rocks

Cambai and Cambaizinho Complexes

Imbicuí Complex

Ultramafic associations (1 to 6 )

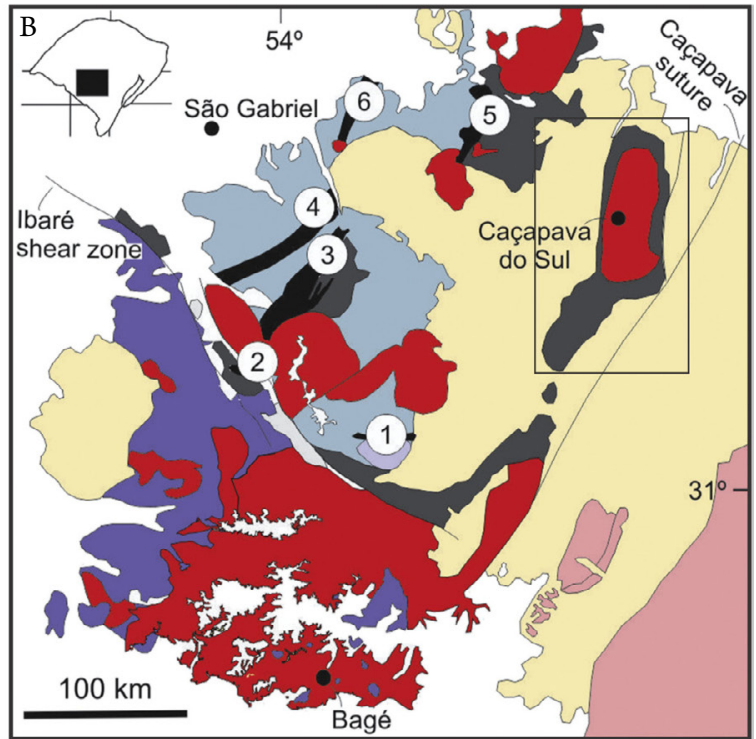

Ultramafic associations
(1) Cerro Mantiqueiras ophiolite
(4) Passo do Ivo
(2) Ibaré ophiolite
(5) Bossoroca
(3) Palma ophiolite
(6) Cambaizinho

Figure 1. (A) Geologic map of southern part of Mantiqueira Province, showing the Dom Feliciano belt (within the Sul-Riograndense shield) in Rio Grande do Sul state, southern Brazil and highlighting the São Gabriel Terrane; (B) geologic map of the São Gabriel Terrane, showing the study area in Caçapava do Sul region. Modified from Arena et al. 2017, with data from Chemale Jr. et al. (1995), Rapela et al. (2007), Hartmann et al. (2007), Laux et al. (2012) and Camozzato et al. (2014). 
The northern and western section of the Passo Feio Complex are composed of metapelites, amphibolites, basic and magnesian schists and metasandstones interleaved with mafic to ultramafic metamorphized rocks, while the south of the Caçapava Granite is made up of garnet-staurolite schists, slates, phyllites and chlorite-epidote schists. In the southern area of the PFMC, there are basalts of the Arroio Mudador Formation, formed in subaqueous environments and shown through the presence of pillow lavas with a paragenesis that includes prehnite and pumpellyite, indicating a low-grade metamorphism (Macedo et al. 1978, Toniolo et al. 2007, Chaves et al. 2010).
The regional metamorphism varies from greenschist to amphibolite facies, preserved by the metamorphic gradient of the chlorite and staurolite zone (Ribeiro et al. 1966, Ribeiro 1970, Remus et al. 2000, Saalmann et al. 2006). Bitencourt (1983) described two regional metamorphic events (M1 and $\mathrm{M} 2$ ) in these rocks. The first one (M1) reaches amphibolite facies, and the second (M2) is retrogressive (greenschist facies), evidenced by partial substitution of staurolite and/or garnet to chlorite in pelitic schists and dolomite substitution to serpentine or talc in marbles. These events were followed by two deformation phases.
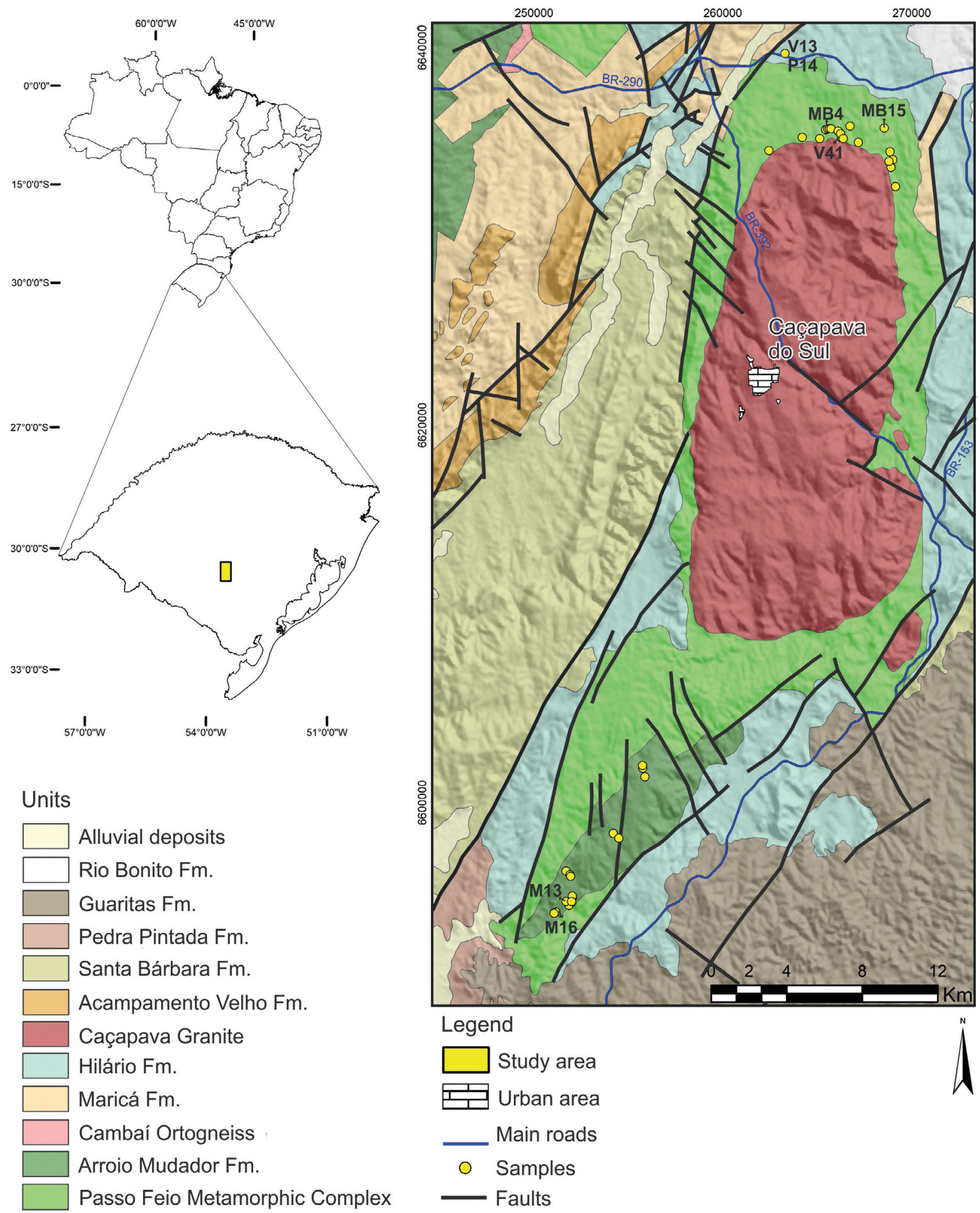

Units

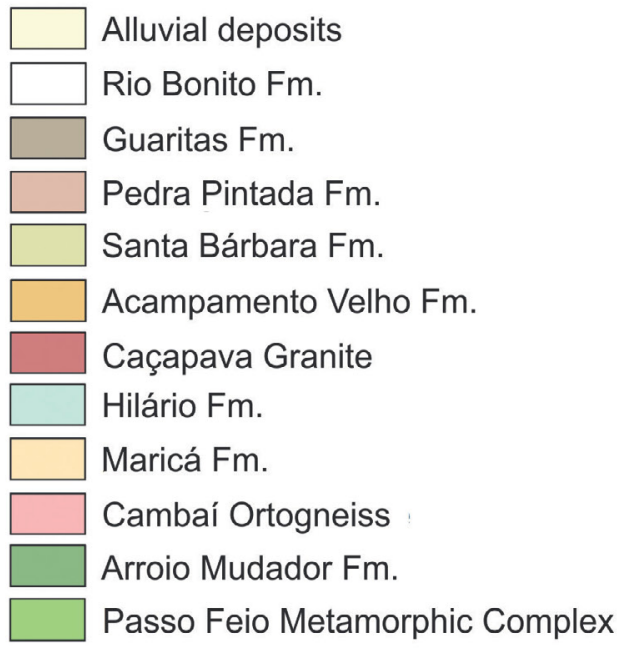

Figure 2. Map of the study area showing the sample locations, highlighting the most relevant samples. 
The Passo Feio Complex metamorphites are arranged in an antiformal structure dipping northwest, with its axis showing a low rake sometimes to the northeast or southwest. At the core of the antiformal structure is the granitic body. The folded metamorphic surface of the PFMC tends to outline the granitic body, acquiring approximately a north-south direction near the east and west borders, and an east-west direction on the north and south borders (Bitencourt 1983).

\section{RESULTS}

\section{Petrography}

The analyzed samples were classified into four different lithology groups based on field description, outcrop, hand samples (macroscopic) and microscopic characteristic evaluations: basalts, pillow lavas, amphibolites and intermediate to mafic dikes. The petrographic analysis was conducted with the Leica DM4500 P LED microscope model with an attached camera (LEICA DFC495 model) through natural light, crossed polarizers and reflected light in order to make the description, mineralogical and textural characterization, in addition to taking the utilized photos. The modal count of representative samples of each lithology is compiled in Table 1.

The basalt and pillow lava are composed of the same mineralogy (augite + chlorite + epidote + prehnite + pumpellyite + white mica + plagioclase + quartz + opaque minerals (titanite, ilmenite and chalcopyrite), with volcanic glass present). The studied samples possess many similarities, like an aphanitic hipocrystalline texture, anhedral to subhedral minerals, originally empty spaces filled with chlorite and almost a complete substitution of plagioclase by white mica and epidote, with rare fragments preserved. But these lithologies have the following unequal characteristics: the basalt is fine to medium-grained with green-colored epidotes that have oxidized borders indicating ferric composition, while the pillow lava is very fine grained with pyroxene having a "branched" growth indicating fast cooling. The pillow lavas have chlorite, epidote (generally colorless) and

Table 1. Modal quantification of representative thin sections of the studied lithologies, with a total of 600 points per sample.

\begin{tabular}{lcccc}
\hline Rock/Mineral (\%) & Basalt & Pillow & Dikes & Amphibolite \\
\hline Augite & 38.2 & 43.8 & 12.2 & - \\
Chlorite & 20.3 & 17.8 & 24.0 & - \\
Plagioclase & 11.0 & 9.0 & 0.0 & 10.0 \\
Actinolite & - & - & 26.3 & 26.5 \\
Hornblende & - & - & - & 43.8 \\
Kaersutite & - & - & 30.5 & - \\
Epidote & 8.2 & 11.8 & 7.0 & 13.7 \\
Prehnite & 13.1 & 9.7 & - & - \\
Pumpeleite & 0.5 & 0.0 & - & - \\
Sericite & 5.7 & 7.2 & - & - \\
Titanite & 2.7 & 0.7 & - & 3.7 \\
Opaque Minerals & 0.3 & 0.0 & - & 2.3 \\
Total & 100 & 100 & 100 & 100 \\
\hline
\end{tabular}

prehnite-filled vesicles. The veins are filled with chlorite, epidote and white mica. Stratigraphically, they were found in the same region (south section of the Passo Feio Complex, individualized in the Arroio Mudador Formation), but they were macroscopically differentiated mainly by pillow lava structures, in which basalts have a massive structure without apparent rapid cooling textures. Macedo et al. (1978) described metabasite outcrops in the study region with a pillow lava structure with the same field aspects and textural and mineralogic characteristics of those analyzed in this paper.

The intermediate to mafic dikes located north of the Caçapava Granite have epidote \pm kaersutite \pm actinolite \pm augite \pm diopside \pm quartz \pm chlorite + plagioclase \pm sericite \pm opaques, with a great mineralogical variation in the described samples. The dikes are fine to medium-grained, with an aphanitic holocrystalline matrix and with anhedral to subhedral minerals. Some pyroxene grains show compositional zoning, identified by a violet-purple color of anomalous interference in crossed polarizers and a pinkish color in natural polarized light — due to Ti presence (Deer $\mathrm{et}$ al. 1992), observed in microprobe analysis. Pyroxene and amphibole cumulates are also found. The plagioclase is, for the most part, substituted by sericite, with rare primary fragments preserved. Two different amphiboles are identified. One is brown-colored, interpreted as primary igneous; though sometimes a substitution of anomalous interference color pyroxenes occurs, and it has kaersutite characteristics. The other is a light green color, interpreted as having a metamorphic origin. It is frequently found in the borders of the brown amphibole or as individual crystals, classified as actinolite. The dikes show a considerable variety in field relations, given the intrusion of more recent dikes in the older ones, with interlobated contacts between the older dikes and straight contacts in the more recent ones. They differ from other lithologies due to their distinct mineralogy and their location in the Hilário Formation, north of PFMC (Fig. 2).

The amphibolites occur in the northern part of the PFMC, interpreted as basic bodies, covering the entirety of this region's outcrops. There is a possibility of being large basic metamorphosed dikes or sills. However, the contacts of these bodies were not found due to the lack of outcrops that show such relations or due to their large dimensions.

The amphibolites are mineralogically composed of actinolite + hornblende + epidote + plagioclase + titanite + opaques (ilmenite), with an orientation defined by the amphiboles. They are fine to coarse-grained, with amphibole-oriented porphyroblasts and a matrix composed of epidote, hornblende, plagioclase, ilmenite and titanite. Most of the minerals are anhedral, with subordinate subedric minerals. In this lithology all minerals are metamorphic, as igneous minerals are not found. Generally, the amphibole has a light green core coloration resembling actinolite and a dark green border coloration (interpreted as hornblende). Sometimes, the grain is entirely composed by hornblende. Titanite is generally found substituting opaque minerals.

\section{Mineral chemistry}

Mineral chemistry analysis was performed using the Cameca SXFive model electronic microprobe of the Laboratório 
de Microssonda Eletrônica da Center of Petrology and Geochemistry Studies (CPGq), Geosciences Institute (IGEO), Universidade Federal do Rio Grande do Sul (UFRGS), by wavelength dispersive spectroscopy (WDS) using $15 \mathrm{keV}$ voltage and $15 \mathrm{nA}$ beam current. The analyzed minerals were pyroxene, epidote, amphibole, plagioclase and chlorite in a total of 474 points in seven polished thin section samples, in which there are: MB-4, MB-15 and V41 (amphibolites), P14 and V13 (dikes), M13 (basalt) and M16 (pillow lava). Table 2 shows the representative minerals of each studied lithology.

\section{Amphibole}

No amphiboles were found in the basalts and pillow lavas. The Leake et al. (1997) classification was used to name the amphiboles (Fig. 3) in the 115 analyzed points. The amphiboles present in the intermediate to mafic dikes are mostly actinolite and magnesiohornblende, with an occurrence of magnesiohastingsite, pargasite, and a large quantity of titanium and kaersutite, of which the last three have a huge petrographic and chemical similarity to each other. These minerals occur mostly as igneous, texturally shown by their anhedral to subhedral shape, generally substituted by actinolite or magnesiohornblende in the borders, but there is also substituting Ti-rich pyroxenes. Actinolite and magnesiohornblende are also found in individual crystals.

In the amphibolites, all minerals have a metamorphic origin, based in textural and mineralogical (paragenesis) aspects. The amphibolites have compositional zoning. A clear core-rim relationship was observed, wherein the core is composed predominantly of actinolite or with a minority of magnesiohornblende. The rim has a ferrohornblende to ferrotschermakite composition with a variation in the composition, indicating a temperature increase related to progressive metamorphism (Fig. 3A). This compositional zoning is also noticeable petrographically in the pleochroism color ranging from colorless to light green in the core and changing from light green to dark green in the borders. Not all minerals have this distinct core-rim characteristic, as a considerable quantity of minerals are homogeneous in composition and color.

\section{Feldspar}

This mineral is found in all studied lithologies as plagioclase, observed through the analysis of 58 points (Fig. 4). The basalt,

A
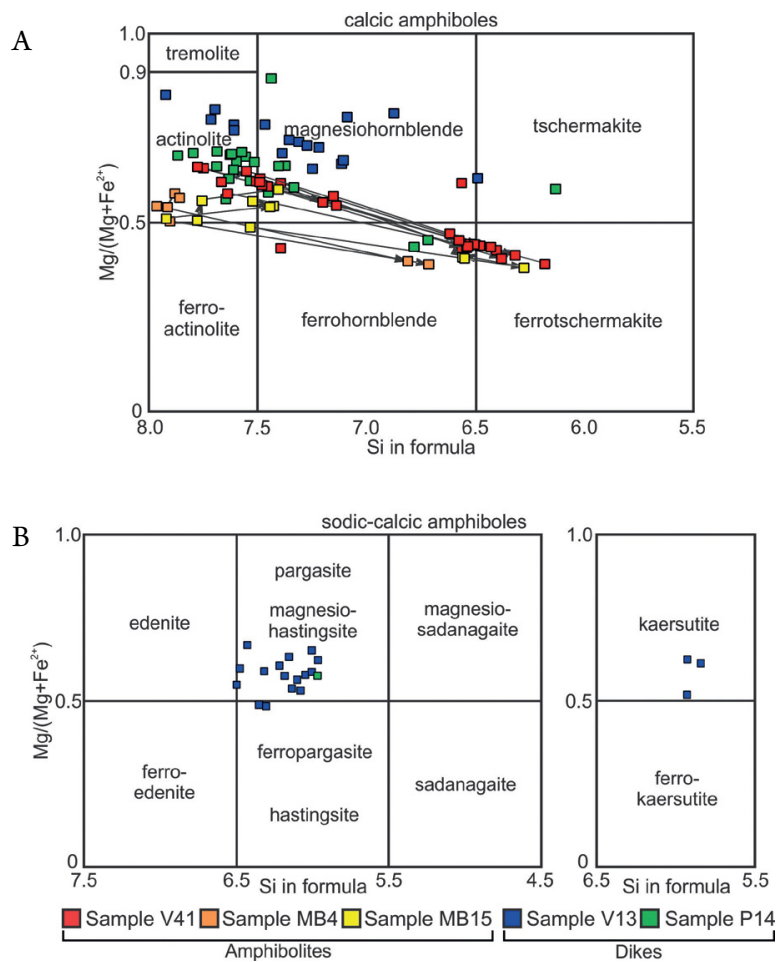

Figure 3. Diagram of calcic and sodic-calcic amphibole classification according to Leake et al. (1997). The arrows indicate the core to rim relationship. Analyzed samples: MB4, MB15 and V41 (amphibolites), V13 and P14 (dikes).

Table 2. Representative samples of analyzed minerals in the electronic microprobe.

\begin{tabular}{|c|c|c|c|c|c|c|c|c|c|c|c|c|c|c|c|c|}
\hline \multirow{2}{*}{$\begin{array}{l}\text { Mineral(wt.\%) } \\
\text { Rock }\end{array}$} & \multicolumn{3}{|c|}{ Piroxene } & \multicolumn{3}{|c|}{ Clorite } & \multicolumn{4}{|c|}{ Epidote } & \multicolumn{4}{|c|}{ Feldspar } & \multicolumn{2}{|c|}{ Amphibole } \\
\hline & Basalt & Pillow & Dikes & Basalt & Pillow & Dikes & Basalt & Pillow & Dikes & Amphib. & Basalt & Pillow & Dikes & Amphib. & Dikes & Amphib. \\
\hline $\mathrm{SiO}_{2}$ & 51.75 & 50.66 & 49.04 & 26.82 & 27.32 & 28.72 & 37.58 & 37.63 & 38.14 & 38.06 & 65.2 & 67.01 & 59.21 & 63.01 & 40.65 & 47.66 \\
\hline $\mathrm{TiO}_{2}$ & 0.61 & 0.78 & 1.25 & 0.02 & 0.01 & 0.06 & 0.00 & 0.03 & 0.03 & 0.08 & 0.02 & 0.02 & 0.52 & 0.00 & 3.37 & 0.08 \\
\hline $\mathrm{Al}_{2} \mathrm{O}_{3}$ & 3.17 & 2.8 & 5.16 & 18.83 & 18.66 & 18.34 & 21.48 & 23.01 & 28.29 & 24.97 & 21.28 & 20.76 & 22.47 & 23.42 & 11.34 & 7.19 \\
\hline $\mathrm{FeO}(\mathrm{t})$ & 7.93 & 11.73 & 6.65 & 28.97 & 25.09 & 17.57 & 15.86 & 13.61 & 6.02 & 11.37 & 0.15 & 0.31 & 2.18 & 0.11 & 13.66 & 16.99 \\
\hline $\mathrm{MnO}$ & 0.2 & 0.27 & 0.15 & 0.29 & 0.21 & 0.24 & 0.07 & 0.06 & 0.06 & 0.16 & n.a. & n.a. & n.a. & n.a. & 0.24 & 0.29 \\
\hline $\mathrm{MgO}$ & 16.56 & 14.38 & 14.75 & 12.2 & 15.46 & 19.37 & 0.02 & 0.02 & 0.05 & 0.02 & 0.03 & 0.00 & 0.64 & 0.00 & 11.85 & 11.48 \\
\hline $\mathrm{CaO}$ & 19.86 & 18.7 & 22.22 & 0.1 & 0.17 & 0.08 & 23.04 & 22.94 & 22.99 & 23.47 & 2.13 & 2.14 & 6.04 & 5.03 & 11.55 & 12.09 \\
\hline $\mathrm{Na}_{2} \mathrm{O}$ & 0.21 & 0.15 & 0.22 & n.a. & n.a. & n.a. & n.a. & n.a. & n.a. & n.a. & 10.39 & 9.76 & 8.18 & 8.89 & 1.91 & 0.69 \\
\hline $\mathrm{K}_{2} \mathrm{O}$ & 0.00 & 0.00 & 0.00 & n.a. & n.a. & n.a. & n.a. & n.a. & n.a. & n.a. & 0.05 & 0.05 & 0.16 & 0.04 & 0.52 & 0.22 \\
\hline $\mathrm{Cr}_{2} \mathrm{O}_{3}$ & 0.11 & 0.14 & 0.45 & 0.00 & 0.02 & 0.51 & 0.00 & 0.01 & 0.01 & 0.01 & n.a. & n.a. & n.a. & n.a. & 0.02 & 0.01 \\
\hline $\mathrm{V}_{2} \mathrm{O}_{3}$ & 0.07 & 0.13 & 0.07 & n.a. & n.a. & n.a. & 0.00 & 0.08 & 0.03 & 0.06 & n.a. & n.a. & n.a. & n.a. & 0.07 & 0.06 \\
\hline $\mathrm{NiO}$ & 0.00 & 0.00 & 0.00 & n.a. & n.a. & n.a. & n.a. & n.a. & n.a. & n.a. & n.a. & n.a. & n.a. & n.a. & 0.04 & 0.01 \\
\hline $\mathrm{Y}_{2} \mathrm{O}_{3}$ & n.a. & n.a. & n.a. & n.a. & n.a. & n.a. & 0.00 & 0.02 & 0.00 & 0.00 & n.a. & n.a. & n.a. & n.a. & 0.00 & 0.00 \\
\hline $\mathrm{F}$ & n.a. & n.a. & n.a. & n.a. & n.a. & n.a. & n.a. & n.a. & n.a. & n.a. & n.a. & n.a. & n.a. & n.a. & 0.00 & 0.00 \\
\hline Total & 100.49 & 99.75 & 99.95 & 87.23 & 86.93 & 84.9 & 98.04 & 97.41 & 95.63 & 98.2 & 99.26 & 100.05 & 99.4 & 100.52 & 95.21 & 96.78 \\
\hline
\end{tabular}

n.a.: not analyzed; amphib.: amphibolite. 
pillow lava and dike plagioclases are igneous, proven by their original euhedral tabular habit, but remaining only fragments due to the recrystallization to other minerals like epidote, albite and mica. The composition varies from albite to andesine, but most are oligoclase.

In the amphibolite there is only metamorphic plagioclase, with a composition ranging from albite to oligoclase. It is not possible to observe a clear core-rim relationship since most crystals analyzed have homogeneous composition, or heterogeneous with a random composition.

\section{Pyroxene}

A total of 120 points of this mineral group were analyzed, found in dikes, basalt and pillow lava in considerable quantities. In the amphibolites, all pyroxene minerals were substituted by amphibole during the metamorphism. They have igneous origin, varying from augite in basalt and pillow lava to diopside (dominant) or augite in the analyzed dike samples - classified after Morimoto (1988) (Fig. 5) — , with a considerable amount of $\mathrm{Ti}\left(1.5\right.$ to $\left.1.8 \% \mathrm{TiO}_{2}\right)$ and $\mathrm{Cr}\left(0.4\right.$ to $\left.0.7 \% \mathrm{Cr}_{2} \mathrm{O}_{3}\right)$, confirming the anomalous birefringence origin observed in the petrographic analysis. An observed core-rim relationship is an increase of $\mathrm{Ti}, \mathrm{Cr}$ and $\mathrm{Al}$ and a $\mathrm{Si}$ decrease in these minerals.

\section{Epidote group}

The epidote occurs in all lithologies, with 99 analyzed points. Using the Franz \& Liebscher (2004) classification, the amphibolite and dike epidotes were all classified as clinozoisites. The composition of these minerals in the pillow lavas are predominantly clinozoisite, with only one sample located
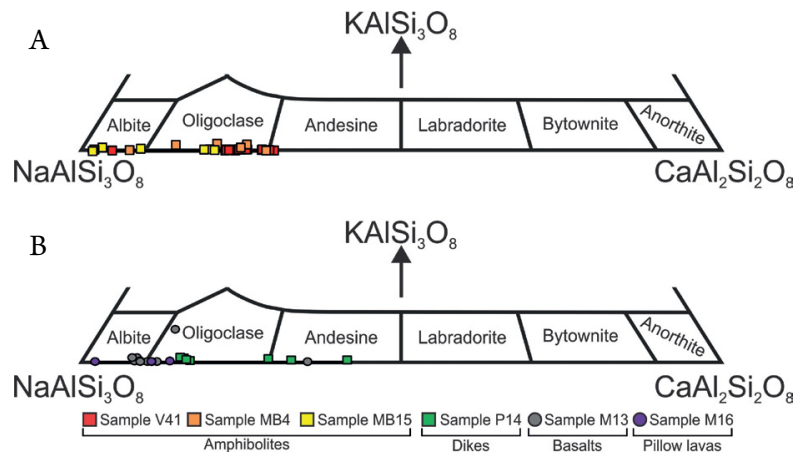

Figure 4. Feldspar classification diagram according to Deer et al. (1992). Part of the diagram was cut for better visualization. Analyzed samples: MB4, MB15 and V41 (amphibolites), P14 (dikes), M13 (basalt) and M16 (pillow lava).

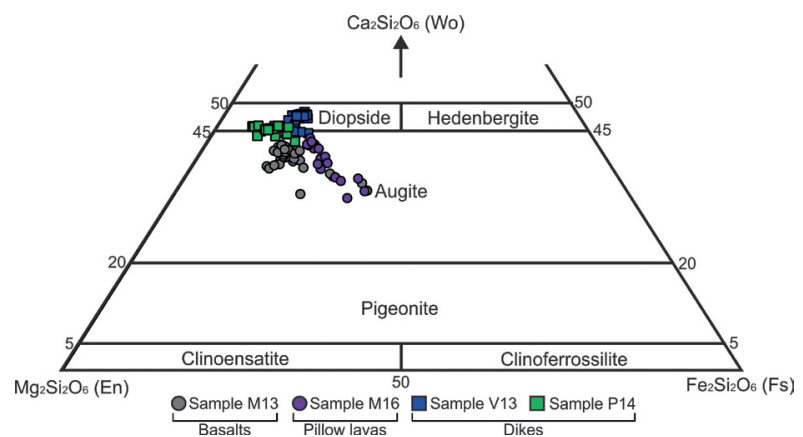

Figure 5. Clinopyroxene classification diagram according to Morimoto (1998). in the epidote field. The basalt has a more ferric composition in the present epidote group minerals, with almost all points analyzed classified as epidote (Fig. 6).

In some analyzed crystals, an $\mathrm{Al}$ increase (Fe decrease) from core to rim was clearly observed in the amphibolite, indicating a temperature elevation in the crystallization process. Most analyzed epidotes do not show this relation.

\section{Chlorite}

Chlorite is not found in the amphibolite lithology, possibly due to a substitution in the metamorphism. The analysis totaled 82 points and it was conducted in the basalt, pillow lava and dike lithologies.

Based on the Zane \& Weiss (1998) classification diagram (Fig. 7A), the chlorites of the two analyzed dike samples are classified as clinochlore because of their magnesian composition. Pillow lava chlorites are also classified as clinochlore, but with an intermediate composition, very close to the chamosite field. Unlike other lithologies, basalt chlorite has a predominance of $\mathrm{Fe}$, classified as chamosite. The Fe-Mg ratio is similar to the whole-rock analysis. A small dispersion (variation in the analysis of the composition of the same sample) is observed, which may indicate a simultaneous chlorite crystallization in each lithology. No significant variation is found in the mineral core-rim relation, as the minerals were found with a homogeneous composition.

To obtain the chlorite crystallization temperature, the Jowett (1991) methodology was applied, which proposes the following formula: $\mathrm{T}\left({ }^{\circ} \mathrm{C}\right)=319^{*} \mathrm{Al}_{\mathrm{c}}^{\mathrm{IV}}-69$, with $\mathrm{Al}_{\mathrm{c}}^{\mathrm{IV}}=$ $\mathrm{Al}^{\mathrm{IV}}+0.1[\mathrm{Fe}(\mathrm{Fe}+\mathrm{Mg})]$, with the $\mathrm{Al}^{\mathrm{IV}}$ and $\mathrm{Fe}^{3+}$ calculated in a spreadsheet proposed by Tindle (2010). Calculated results were plotted in the temperature by $\mathrm{Si}$ (apfu) (Caritat et al. 1993) (Fig. 7B). The M13 (basalt) and M16 (pillow lava) samples generated similar temperatures with the major value concentration between 280 and $315^{\circ} \mathrm{C}$, which, according to the Winter (2014) metamorphic facies graph, estimates the pressure as the average of regional metamorphism - using the Brown \& Mussett (1993) average continental geotherm - ,
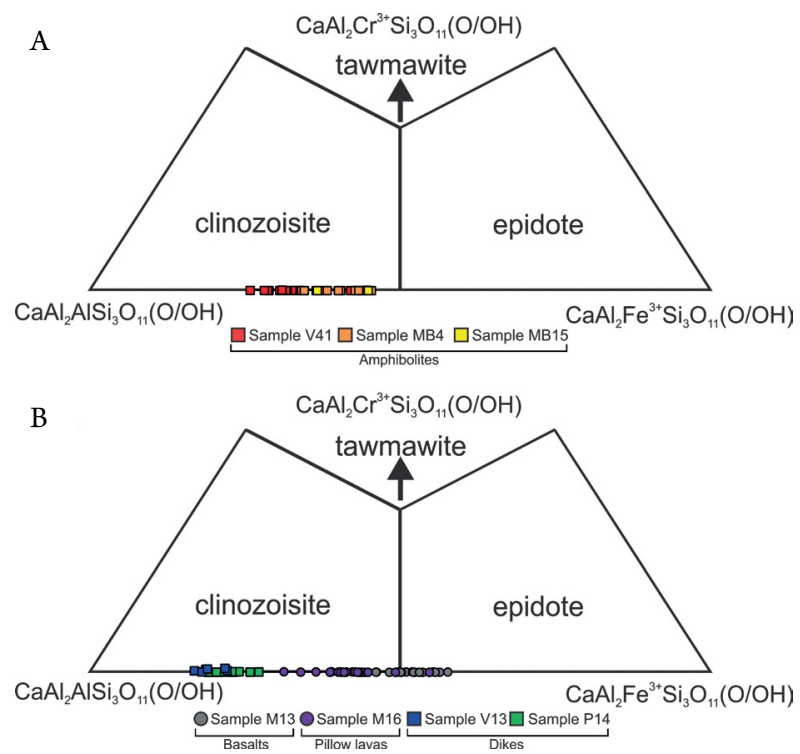

Figure 6. Epidote classification diagram according to Franz \& Liebscher (2004). The Cr (tawmanite) field was cut for better visualization. 
and classified these lithologies in the prehnite-pumpellyite to greenschist transition facies, but mostly in prehnite-pumpellyite. The V13 (dike) sample generated scattered data with low sample variety, making it impossible to be consistently interpreted. The P14 sample (dike) has temperatures between 280 and $332^{\circ} \mathrm{C}$, with a major value concentration between 315 and $332^{\circ} \mathrm{C}$, well-adjusted in the greenschist facies.

\section{Geochemistry}

The whole-rock chemical analysis was conducted using X-ray fluorescence in the Laboratory of Rocks Chemical Analysis of IGEO, UFRGS, consisting of major and trace elements in a total of six samples, and by $\mathrm{LiBO} 2 / \mathrm{LiB} 4 \mathrm{O} 7$ fusion Inductive Coupled Plasma - Mass Spectrometry method conducted in the ACME Labs in a total of 19 samples, which resulted in a major, trace and rare earth element (REE) analysis (STD SO-18 standard). Table 3 summarizes the analyzed lithologies with selected and representative samples for the different groups. The chemical analysis of all samples can be found in the Supplementary Material of the paper.

The samples were chemically classified by major and trace elements using the total alkali silica (TAS) (Le Bas et al. 1986) and $\mathrm{Zr} / \mathrm{TiO}_{2}-\mathrm{Nb} / \mathrm{Y}$ (Winchester \& Floyd 1977) diagrams respectively (Figs. 8A and 8B). The basalt, pillow lava and amphibolite samples were predominantly classified as basalt to basaltic andesite, with the exception of two samples. It shows a compositional similarity between these three studied lithologic groups despite the mineralogical differences. The intermediate dikes were classified as andesite and the mafic ones as basalt and picrobasalt. The $\mathrm{Zr} / \mathrm{TiO}_{2}-\mathrm{Nb} / \mathrm{Y}$ diagram uses immobile elements (valid for terranes up to medium grade metamorphism). Two dike samples show a transitional composition to alkali basalt, which may indicate an alkaline composition of protolith.

The geochemical affinity of the studied rocks was determined in the $\mathrm{Nb} / \mathrm{Y}-\mathrm{Zr} / \mathrm{P}_{2} \mathrm{O}_{5}$ (Floyd \& Winchester 1975), $\mathrm{TiO}_{2}-\mathrm{Zr} / \mathrm{P}_{2} \mathrm{O}_{5}$ (Winchester \& Floyd 1976) and $\mathrm{P}_{2} \mathrm{O}_{5}-\mathrm{Zr}$ (Winchester \& Floyd 1976) discriminant diagrams (Fig. 9). A clear tholeiitic affinity was observed in the basalt, pillow lava and amphibolite samples, with a low variation and similar

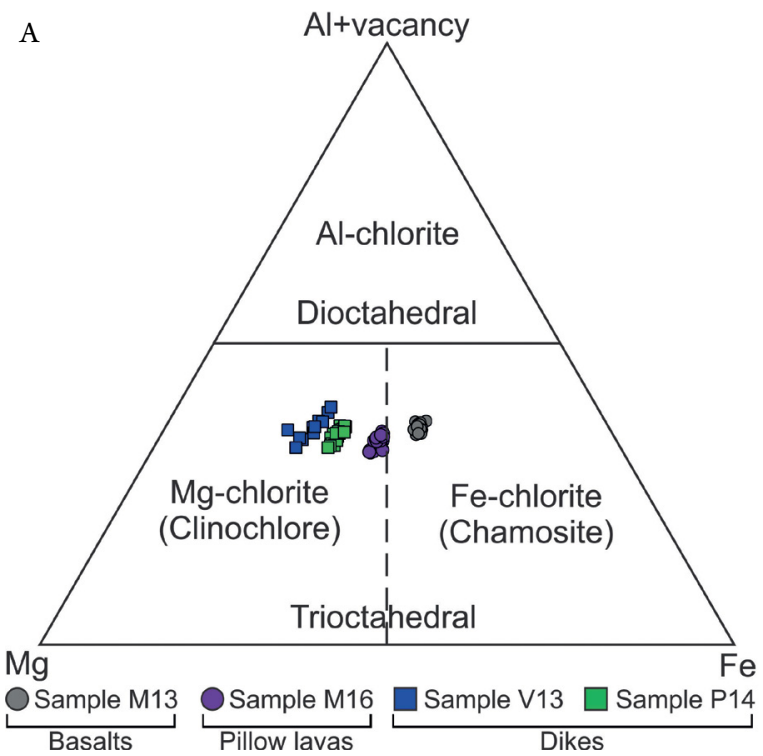

results to each other. The dikes have from tholeiitic to alkaline affinity, which can suggest more than one magmatic pulse.

\section{DISCUSSION}

According to petrographic, mineralogic, whole-rock chemical composition and mineral chemistry observations, the basalt and pillow lava have large similarities and can be interpreted as being formed by the same magma, though solidified in different depths. The pillow lavas are formed in subaqueous environment with rapid cooling, and the basalt is formed in greater depths, given the coarser granulation and absence of rapid cooling textures. Some of these occurrences could represent sills. The chlorite geothermometer in these two lithologies provided temperatures between 280 and $315^{\circ} \mathrm{C}$ in the transition from prehnite-pumpellyite to lower greenschist facies, predominantly in prehnite-pumpellyite. However, the absence of amphibole (actinolite) and their mineral paragenesis implies that there was not enough temperature to equilibrate in the greenschist facies.

The amphibolites register a progressive metamorphism, with amphiboles showing cores composed of actinolite and magnesiohornblende and rims with ferrohornblende and ferrotschermakite compositions (Fig. 3) and an increase in the $\mathrm{Al} / \mathrm{Fe}$ ratio in some epidote grains. The predominant presence of oligoclase and subordinate presence of albite coexisting with tschermakite indicate lower amphibolite facies next to the greenschist facies transition.

According to Grapes \& Hoskin (2004), there is a compositional relation in low to medium-grade metamorphic rocks, defined by the gradual Fe reduction (substituted by Al) with the increase of metamorphic grade. This compositional variation was observed in the higher percentage of $\mathrm{Fe}$ in the basalt and pillow lava epidotes in relation to amphibolite, which allows the comparison from the compositional similarity of these rocks. Dikes should not be considered in this relation, since the low abundance of $\mathrm{FeO}$ and the high $\mathrm{MgO}$ in them directly influence the relatively rich $\mathrm{Al}_{2} \mathrm{O}_{3}$ composition of its epidotes. The $\mathrm{Fe}$ and

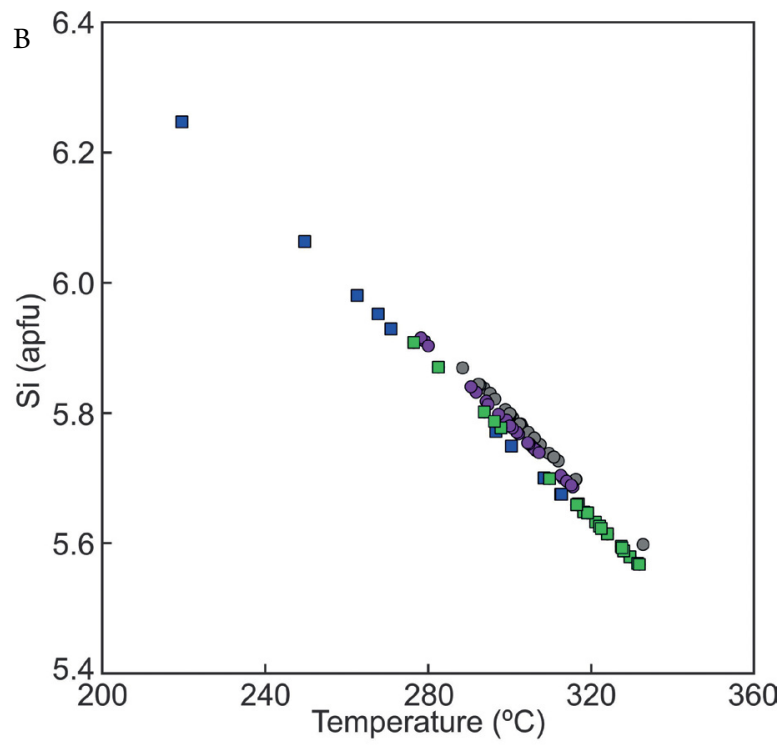

Figure 7. (A): Chlorite classification diagram by Zane \& Weiss (1998); (B) temperature $\times$ Si (apfu) diagram of Caritat et al. (1993). 
Al variation observed among the epidotes of the different lithologies allows a comparison only between the amphibolite, basalt and pillow lava lithologies, due to the similar composition between these in the whole-rock chemistry.
The compositional relation of Grapes \& Hoskin (2004) is observed in the high $\mathrm{Al}$ proportion in the epidotes from amphibolites, indicating a higher metamorphic grade in the amphibolite than in the basalt and pillow lava. The slightly

Table 3. Whole-rock geochemical data of eight representative samples. The major elements are represented in weight $\%$ and the trace elements in ppm.

\begin{tabular}{|c|c|c|c|c|c|c|c|c|}
\hline \multirow{2}{*}{$\begin{array}{l}\text { Rock } \\
\text { Sample }\end{array}$} & \multicolumn{2}{|c|}{ Basalt } & \multicolumn{2}{|c|}{ Pillow } & \multicolumn{2}{|c|}{ Dikes } & \multicolumn{2}{|c|}{ Amphibolite } \\
\hline & M13 & M08 & M15 & M18 & V14 & V12 & MB28 & MB15 \\
\hline $\mathrm{SiO} 2$ & 48.31 & 49.32 & 48.54 & 49.93 & 42.79 & 57.68 & 49.26 & 49.94 \\
\hline $\mathrm{TiO} 2$ & 0.83 & 1.44 & 1.22 & 0.87 & 1.43 & 0.77 & 0.78 & 1.42 \\
\hline $\mathrm{Al} 2 \mathrm{O} 3$ & 13.85 & 13.37 & 15.04 & 14.27 & 11.29 & 16.11 & 15.96 & 12.48 \\
\hline $\mathrm{FeO}(\mathrm{t})$ & 11.18 & 14.6 & 12.48 & 11.36 & 13.52 & 8.54 & 9.05 & 14.01 \\
\hline $\mathrm{MnO}$ & 0.18 & 0.21 & 0.2 & 0.17 & 0.24 & 0.14 & 0.14 & 0.24 \\
\hline $\mathrm{MgO}$ & 7.34 & 5.51 & 7.08 & 7.86 & 14.99 & 5.1 & 5.57 & 5.98 \\
\hline $\mathrm{CaO}$ & 11.52 & 9.74 & 8.11 & 10.46 & 10.25 & 4.58 & 16.89 & 9.31 \\
\hline $\mathrm{Na} 2 \mathrm{O}$ & 1.43 & 0.93 & 3.14 & 1.67 & 0.57 & 2.93 & 0.03 & 2.81 \\
\hline $\mathrm{K} 2 \mathrm{O}$ & 0.25 & 0.29 & 0.92 & 0.77 & 0.56 & 0.9 & 0.18 & 0.19 \\
\hline $\mathrm{P} 2 \mathrm{O} 5$ & 0.06 & 0.1 & 0.19 & 0.1 & 0.22 & 0.1 & 0.06 & 0.12 \\
\hline L.O.I. & 4.38 & 4.3 & 2.8 & 2.2 & 3.59 & 2.38 & 2.28 & 1.56 \\
\hline Total & 99.33 & 99.81 & 99.72 & 99.66 & 99.44 & 99.23 & 100.2 & 98.06 \\
\hline Cs & 0.4 & 0.9 & 0.5 & 0.6 & n.a. & n.a. & 0.5 & 0.1 \\
\hline $\mathrm{Rb}$ & 9.3 & 12.9 & 19.8 & 22.3 & n.d. & n.d. & 9.4 & 3.7 \\
\hline $\mathrm{Ba}$ & 151 & 293 & 995 & 219 & 114.1 & 337.3 & 51 & 85 \\
\hline $\mathrm{Sr}$ & 184.8 & 182.1 & 263.4 & 193.7 & 298.2 & 422.1 & 67.6 & 84.9 \\
\hline $\mathrm{Pb}$ & n.a. & n.a. & n.a. & n.a. & 6.9 & 1.9 & n.a. & n.a. \\
\hline Co & 53,0 & 50.5 & 52.5 & 51.2 & 92.5 & 50 & 54.9 & 55.8 \\
\hline $\mathrm{Ga}$ & 17.2 & 21.4 & 18.9 & 16.7 & 15.8 & 18.9 & 23.8 & 19.4 \\
\hline $\mathrm{Cr}$ & n.a. & n.a. & 294.2 & 444.7 & 1450.7 & 169.1 & n.a. & n.a. \\
\hline V & 284 & 390 & 263 & 265 & n.a. & n.a. & 251 & 428 \\
\hline $\mathrm{Nb}$ & 4.8 & 4.2 & 9.4 & 4.8 & 18 & 4.2 & 4.1 & 1.6 \\
\hline $\mathrm{Ta}$ & 0.3 & 0.2 & 0.5 & 0.3 & n.a. & n.a. & 0.2 & 0.1 \\
\hline $\mathrm{Zr}$ & 69.8 & 92.5 & 123.5 & 73 & 66.3 & 95.8 & 75.3 & 66.9 \\
\hline Hf & 1.9 & 3.1 & 3.2 & 2.4 & n.a. & n.a. & 2 & 2.2 \\
\hline Th & 2.6 & 1.2 & 2.1 & 2 & n.a. & n.a. & 2 & $<0.2$ \\
\hline $\mathrm{U}$ & 2.1 & 0.2 & 0.3 & 0.3 & n.a. & n.a. & 0.4 & 0.1 \\
\hline Y & 16.9 & 25.7 & 19.8 & 15.3 & 24.8 & 25.3 & 15.6 & 31.8 \\
\hline $\mathrm{La}$ & 8.2 & 8.1 & 19.6 & 10 & n.a. & n.a. & 15 & 3 \\
\hline $\mathrm{Ce}$ & 17.2 & 18.6 & 40 & 21.5 & n.a. & n.a. & 29.6 & 8.4 \\
\hline $\operatorname{Pr}$ & 2.24 & 2.71 & 4.82 & 2.66 & n.a. & n.a. & 3.51 & 1.5 \\
\hline $\mathrm{Nd}$ & 10.5 & 13.2 & 18.9 & 10.7 & n.a. & n.a. & 14.6 & 7.7 \\
\hline Sm & 2.5 & 3.56 & 4.14 & 2.65 & n.a. & n.a. & 3.05 & 2.97 \\
\hline $\mathrm{Eu}$ & 0.94 & 1.25 & 1.44 & 0.85 & n.a. & n.a. & 0.94 & 1.16 \\
\hline $\mathrm{Gd}$ & 2.87 & 4.48 & 4.03 & 2.95 & n.a. & n.a. & 3.18 & 4.34 \\
\hline $\mathrm{Tb}$ & 0.52 & 0.79 & 0.67 & 0.48 & n.a. & n.a. & 0.52 & 0.83 \\
\hline Dy & 3.34 & 4.54 & 3.66 & 2.91 & n.a. & n.a. & 3.03 & 5.39 \\
\hline Ho & 0.66 & 0.96 & 0.72 & 0.6 & n.a. & n.a. & 0.57 & 1.11 \\
\hline $\mathrm{Er}$ & 1.79 & 2.58 & 2.07 & 1.72 & n.a. & n.a. & 1.67 & 3.68 \\
\hline $\mathrm{Tm}$ & 0.28 & 0.42 & 0.28 & 0.24 & n.a. & n.a. & 0.25 & 0.55 \\
\hline $\mathrm{Yb}$ & 1.74 & 2.42 & 1.89 & 1.61 & n.a. & n.a. & 1.55 & 3.35 \\
\hline $\mathrm{Lu}$ & 0.24 & 0.35 & 0.31 & 0.23 & n.a. & n.a. & 0.23 & 0.49 \\
\hline
\end{tabular}

n.a.: not analyzed; n.d.: not detected. 
higher percentage of $\mathrm{Al}$ in the pillow lava compared to the basalt does not represent a difference of metamorphic grade, proven by the mineralogical similarity and, therefore, paragenetic. The chlorites do not have compositional zoning, and therefore do not show variations that indicate metamorphic conditions, as their composition is similar to the whole-rock composition (crystallizing in this way because of the proportion of chemical elements it has).
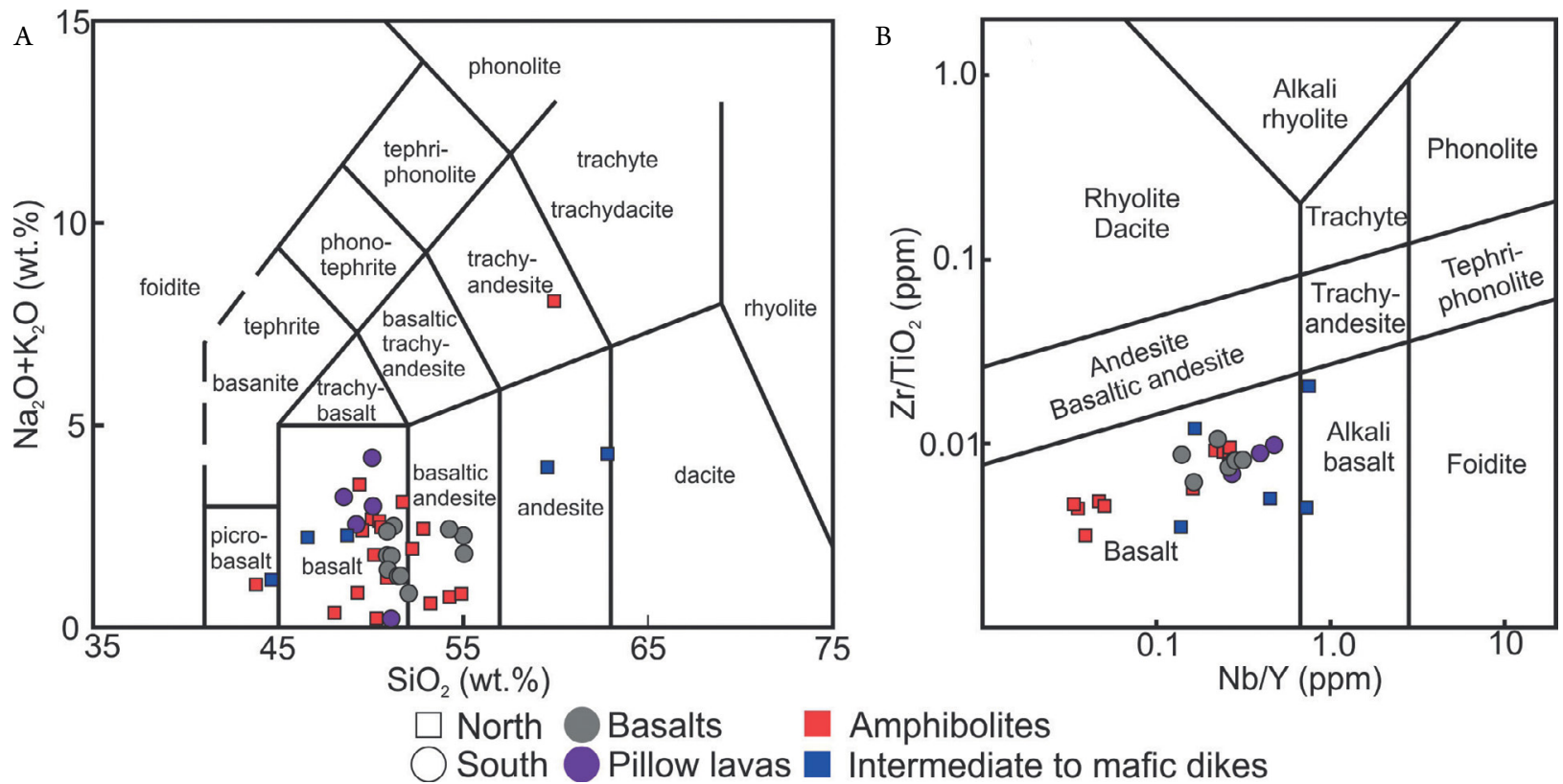

Figure 8. (A) Volcanic rock classification diagram through chemical composition TAS (total alkali silica) (Le Bas et al. 1986); (B) volcanic rock classification diagram through trace elements $\mathrm{Zr} / \mathrm{TiO} 2-\mathrm{Nb} / \mathrm{Y}$ (Winchester \& Floyd 1977).
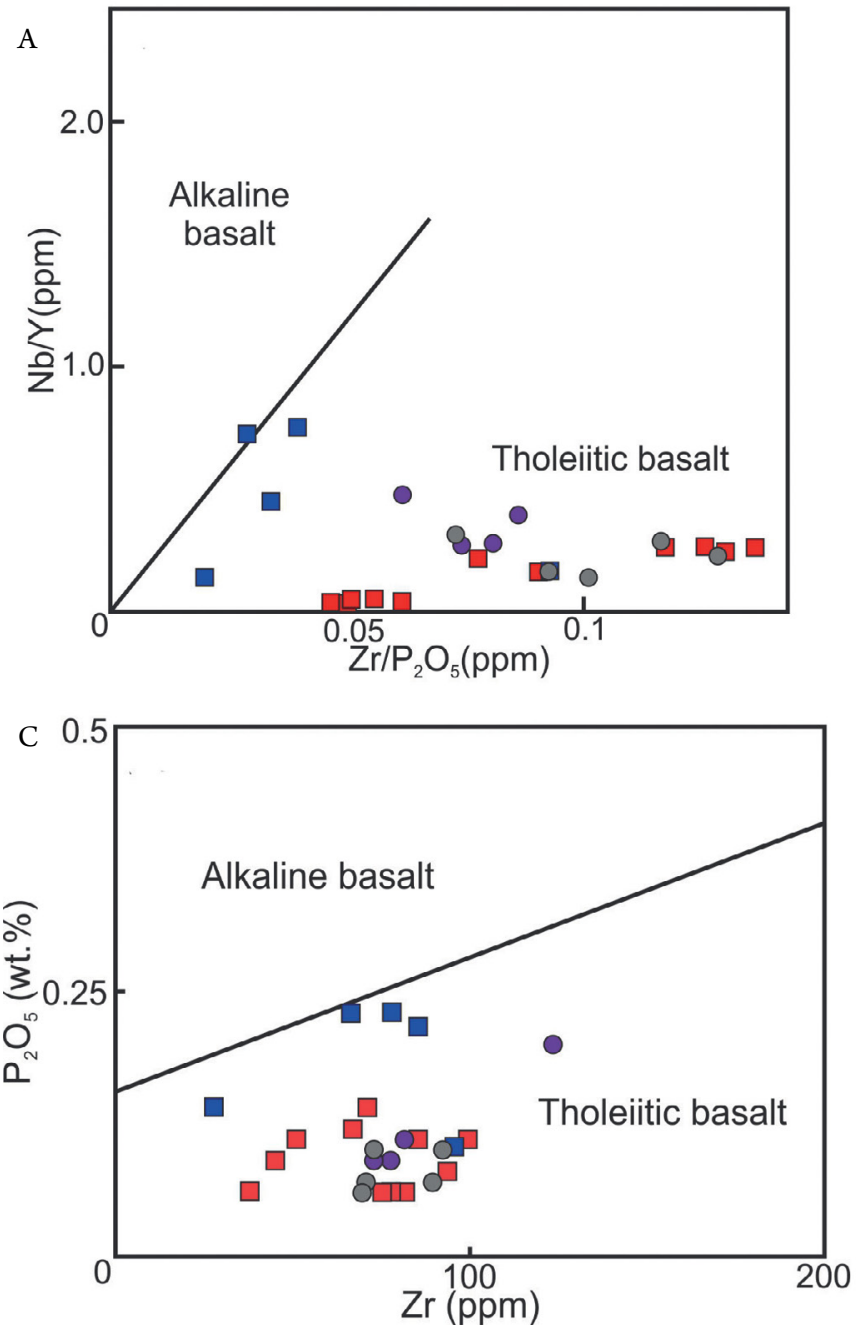

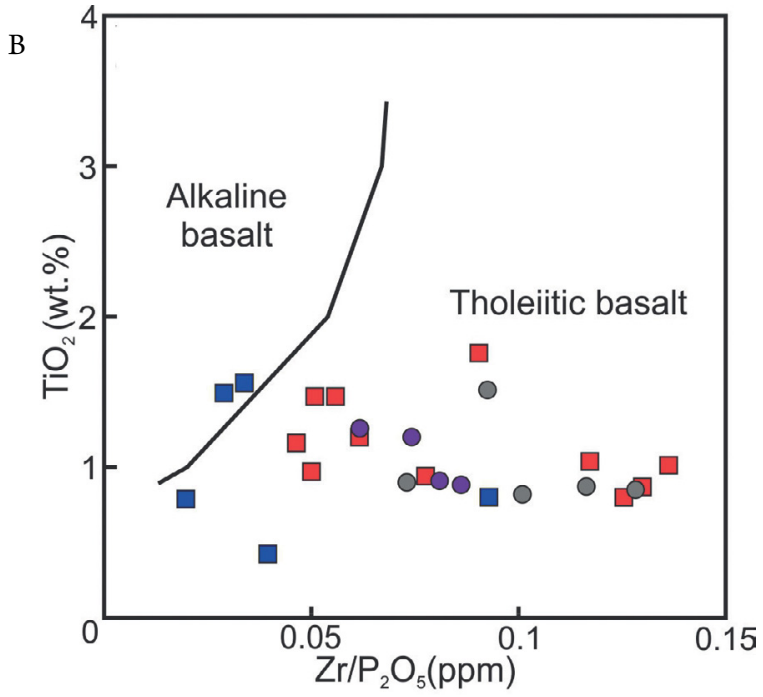

North Basalts

South Pillow lavas

Amphibolites

Intermediate to mafic dikes

Figure 9. Basalt geochemical affinity classification diagrams. (A) Nb/Y $\times \mathrm{Zr} / \mathrm{P} 2 \mathrm{O} 5$ (Floyd \& Winchester 1975); (B) $\mathrm{TiO} 2 \times \mathrm{Zr} / \mathrm{P} 2 \mathrm{O} 5$ (Winchester \& Floyd 1976); (C) Zr-P2O5 wt.\% (Winchester \& Floyd 1976). 
The rock classification diagram by the whole-rock analysis and geochemical affinity discriminant diagrams show a geochemical similarity among basalt, pillow lava and amphibolite lithologies. The three lithologies have a basaltic to basaltic-andesite composition and tholeiitic affinity, derived from the same protolith. The contrasting mineralogical features are due to different metamorphic grades. The similarity between the classification of Figures $8 \mathrm{~A}$ and $8 \mathrm{~B}$ diagrams indicates that there was little contamination in the metamorphism, due to the fact that the $\mathrm{Zr} / \mathrm{TiO}_{2}-\mathrm{Nb} / \mathrm{Y}$ diagram uses immobile elements up to medium grade metamorphism.

The Leterrier et al. (1982) diagrams (Figs. 10A, 10B and $10 \mathrm{C}$ ), utilized in sequence to geochemistry affinity determination of the analyzed rocks through clinopyroxenes show with accurate precision the alkaline affinity of the dike sample V13 and tholeiitic in P14 sample, possibly indicating different magmas in the same event. The basalt (M13) has transitional tholeiitic to calc-alkaline affinity and the pillow lava (M16) has tholeiitic character. The basalt (M13) and pillow lava (M16) plot in the non-orogenic field in Figure 10B, while the P14 (dike) sample is plotted in the orogenic field. The $\mathrm{P} 14$ points plot in an unexpected field and, therefore, the classification scheme is not diagnostic of the geotectonic environment for dikes. In the Le Bas (1962) diagram (Fig. 10D), the basalt, pillow lava and tholeiitic dike results are consistent with the previous diagrams showing subalkaline affinity. The V13 (dike) sample previously classified in the diagrams as alkaline showed subalkaline to peralkaline affinity, presenting consistency. Most of the points with alkaline and peralkaline character are in the pyroxenes rim, showing an increase of alkalinity as a core-rim relationship in this sample.

The petrographic and mineral chemistry analysis in a mafic dike shows a large presence of sodic-calcic amphiboles (magnesiohastingsite) with petrographic features of kaersutite. The chemical composition of some analysis of this amphibole can be classified as kaersutite, and others have a similar composition (high Ti content, but not enough to be classified as kaersutite) (Fig. 3B). The actinolite presence in the observed metamorphic paragenesis, the absence of higher temperature amphiboles and the chlorite geothermometer with 315 to $332^{\circ} \mathrm{C}$ temperatures indicate lower greenschist facies for the dikes.

Intermediate to mafic dikes have a geochemical affinity from tholeiitic to alkaline, probably due to chemical variations of the different magmatic pulses (or alternatively by
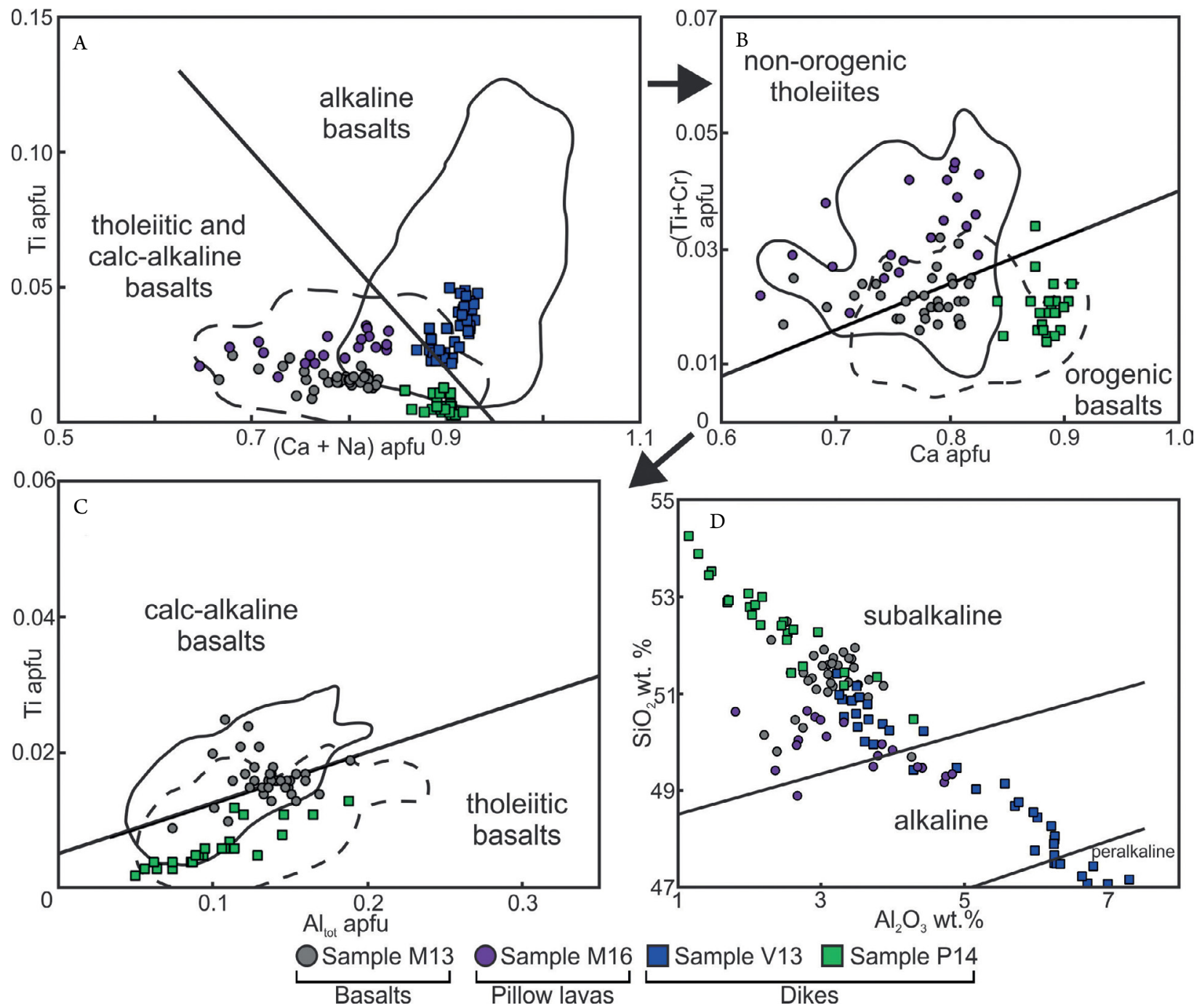

Figure 10. (A), (B) and (C) Discriminant diagrams using clinopyroxenes according to Leterrier et al. (1982) to geochemical affinity and geotectonic environment classification. The arrows show the subsequent utilization order for correct classification. The continuous and dashed lines show the areas of greatest frequency from the author's analyzed samples of each classification field. (D) Geochemical affinity discriminant diagram after Le Bas (1962). 
crustal contamination or assimilation). The alkaline character is indicated by the high amount of $\mathrm{Cr}, \mathrm{Ti}$ and $\mathrm{Al}$ and the clinopyroxene and whole-rock geochemical affinity diagrams. The kaersutite is a typical component of alkaline volcanic rock, as an igneous mineral and also replacing titaniferous augites (Deer et al. 1992), as both are features found in the mafic dike (sample V13). Therefore, the dikes intruded in the Hilário Formation have clear differences from the other lithologies. However, the available geochronological data for the metabasites do not yet allow a conclusion about whether the metamorphic evolution of these lithologies found in PFMC was or was not contemporaneous to that of the dikes.

The utilized geotectonic environment discriminant diagrams produced similar data between themselves. The $\mathrm{MnO}-\mathrm{TiO}_{2}-\mathrm{P}_{2} \mathrm{O}_{5}$ (Mullen 1983) (Fig. 11A) diagram produced a cluster of points in the island arc tholeiites (IAT) field. With a similar result, the chemical analysis plotted in the Th-Hf-Ta (Wood et al. 1979) (Fig. 11B) diagram were located in the volcanic arc basalts (VAB) field (IAT are included in this classification), with the advantage of not having overlapped classification fields in this diagram. The Zr-Nb-Y (Meschede 1986) (Fig. 11C) generated results in overlapping classification fields, ranging from within-plate tholeiites and $\mathrm{VAB}$ to normal type mid-ocean ridge basalts (N-MORB) and VAB. Lastly, the Zr-Ti-Y (Pearce \& Cann 1973) (Fig. 11D) diagram shows data predominance in the MORB and VAB overlapping field, although some samples were located in the VAB fields.

The data obtained and displayed in the discriminant diagrams of Figure 11 indicate a formation environment of the analyzed rocks in $\mathrm{VAB}$, occurring even in overlapping fields. The points that plot on the within-plate tholeiite field are not found in more than one diagram, and the MORB signature rocks can possibly form in the volcanic arc environment proposed in this paper.

According to Xia (2014) and Xia et al. (2008), the arc basalts and contaminated continental basalts have negative $\mathrm{Nb}$, Ta and $\mathrm{Ti}$ anomalies (in relation with primitive mantle), leading to a misinterpretation about the environment. The $\mathrm{Zr}$ concentration in arc basalts is usually below $130 \mathrm{ppm}$ and below $3.3 \mathrm{Zr} / \mathrm{Y}$ ratio. In continental basalts, these values are above $70 \mathrm{ppm}$ of $\mathrm{Zr}$ and above $3.4 \mathrm{Zr} / \mathrm{Y}$ (regardless of its contamination). The samples have between 37 and $123 \mathrm{ppm}$ of $\mathrm{Zr}$ (76 ppm in average) and 0.7 to 4.95 in $\mathrm{Zr} / \mathrm{Y}$ ratio (3.7 in average) (Fig. 12A). Uncontaminated and contaminated continental
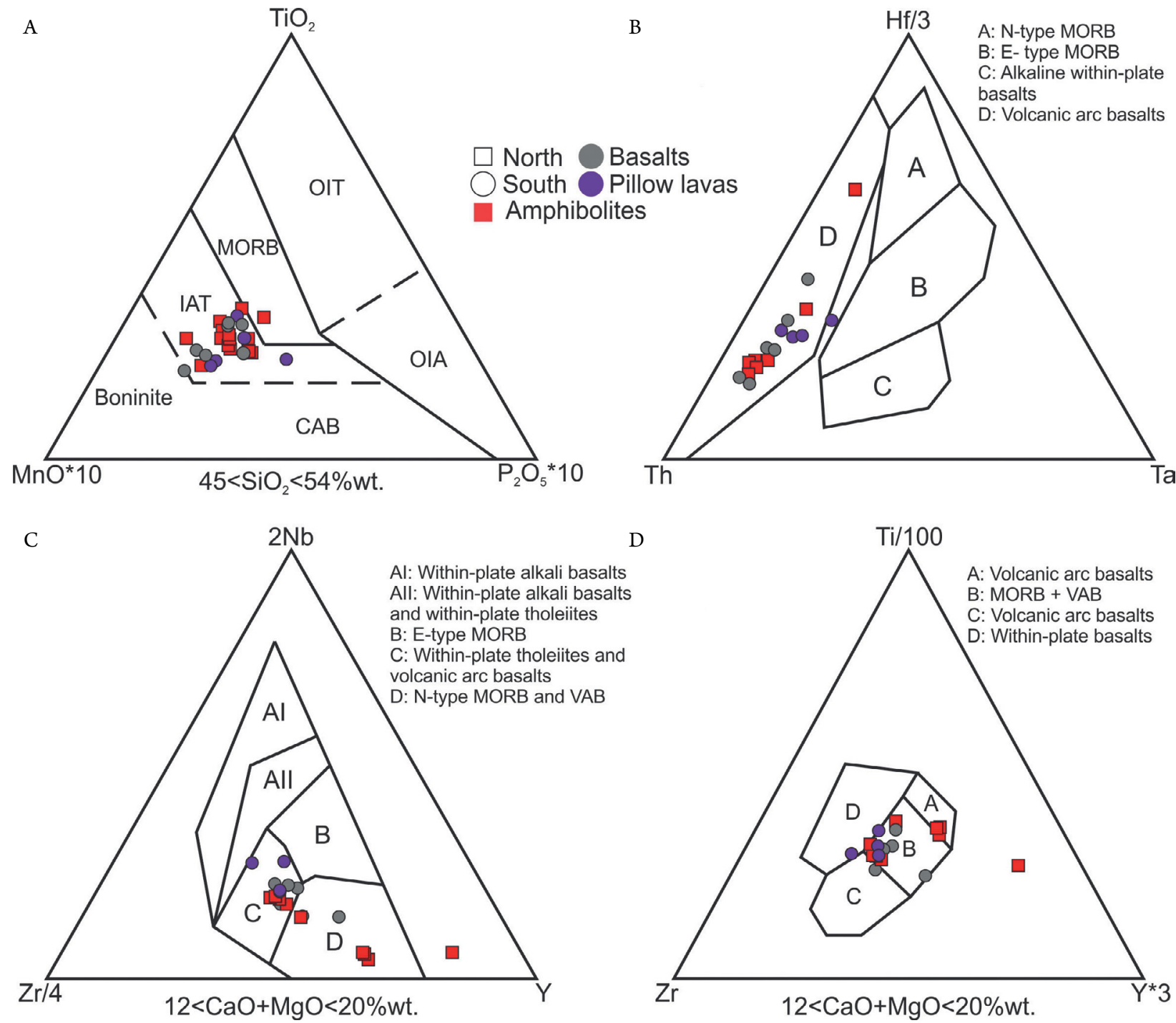

$\mathrm{D}$

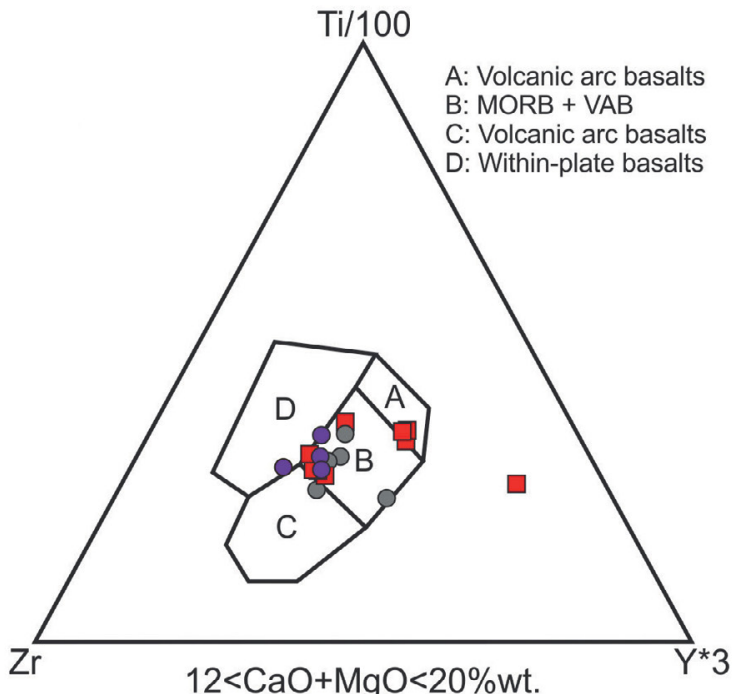

Figure 11. Geotectonic environment discriminant diagrams. (A) MnO-TiO2-P2O5 (Mullen 1983). (B) Th-Hf-Ta (Wood et al. 1979). (C) Zr-Nb-Y (Meschede 1986). (D) Zr-Ti-Y (Pearce \& Cann 1973). 
basalts have similar $\mathrm{Nb}$ concentrations (7-49 ppm), but different $\mathrm{Nb} /$ La ratios $(>1.0$ and $<1.0$, respectively), while the modern arc basalt have low $\mathrm{Nb}(<1.2 \mathrm{ppm})$ and $\mathrm{Nb} / \mathrm{La}$ ratio $(<0.7)$. The analyzed samples in this paper have 0.8 to $9 \mathrm{ppm}$ of $\mathrm{Nb}$ (4.18 ppm in average) and 0.19 to $0.76 \mathrm{Nb} / \mathrm{La}$ ratio ( 0.46 in average), indicating intermediary results between an arc basalt and contaminated continental basalt (Fig. 12B).

These values also show intermediary results between arc basalt and contaminated continental basalts. The $\mathrm{Zr}-\mathrm{Zr} / \mathrm{Y}$ diagram (Pearce \& Norry 1979) shows a cluster of samples next, but outside, of the within plate basalts field and some samples plotted in this field. Samples also occur in the overlapping field between island arc basalts (IAB) and MORB, indicating two different classifications, but most samples close to the continental basalts.

The two major differences in the classification seen in the previously cited diagram are found also in the primitive mantle normalized incompatible trace element spider diagram (after Sun \& McDonough 1989) (Fig. 12C). The samples showing a more negative $\mathrm{Nb}$ and $\mathrm{Ta}$ anomaly are the same plotted in the overlapping field between $\mathrm{ABB}$ and MORB in Figure 12B, which can indicate more than one basalt formation event (continental and arc basalts). The incompatible trace elements above the subduction basalts average also indicates a presence of contaminated continental basalts.

$\mathrm{VAB}$ interpretation is also indicated by the results in Figure 13. The spidergram proposed by Dilek \& Furnes $(2011,2014)$ shows a similarity between the analyzed rocks

A

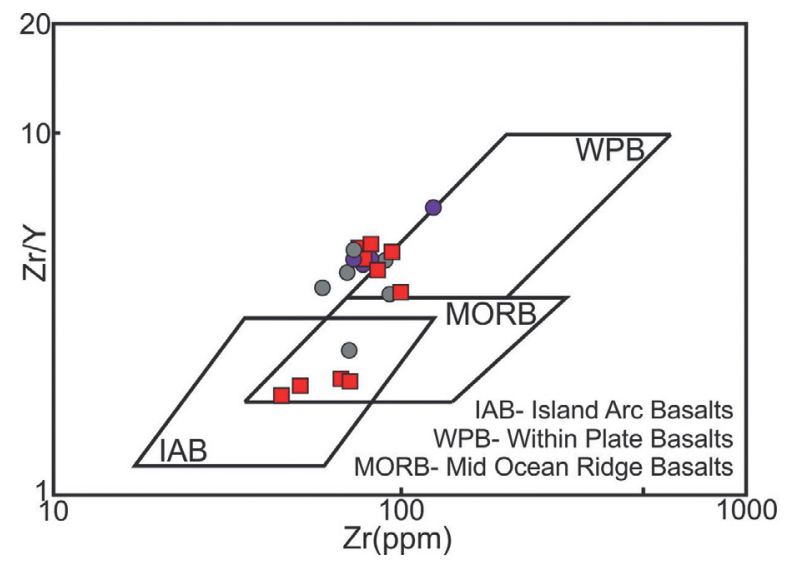

C

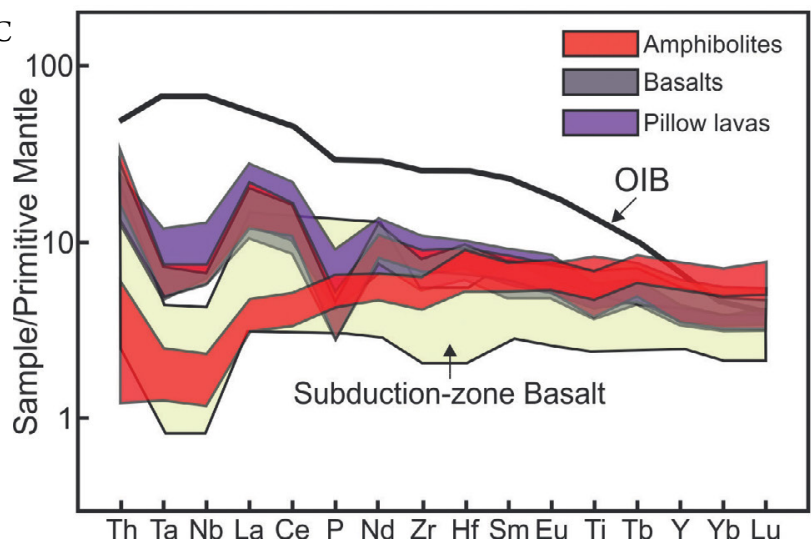

and the volcanic arc ophiolites. Due to a lack of $\mathrm{Pb}$ analysis of basalt and pillow lava, it was not possible to identify the positive anomaly that occurs according to the authors' proposal, but the $\mathrm{Pb}$ analysis of one sample of amphibolite agrees with this $\mathrm{Pb}$ anomaly.

The $\mathrm{Th} / \mathrm{Yb}-\mathrm{Ta} / \mathrm{Yb}$ (Pearce 1982) diagram shows an ocean island arc formation environment, with a predominance of calc-alkaline and a subordinance of tholeiitic, which is consistent with the results obtained in Figure 11 diagrams. However, the geochemical affinity occurs in a different way, justified by a possible transitional character from tholeiitic to calc-alkaline of the studied lithologies - also observed in the Leterrier et al. (1982) diagrams. The V-Ti (Shervais 1982) diagram classifies the samples in IAB and MORB (close to the transition line between them), also coinciding with the proposed volcanic arc model. Dilek \& Furnes (2011) reclassified this diagram with a large sample variety (Fig. 5B of the cited article), with the samples of this paper matching the volcanic arc ophiolite samples occurrence area from the diagram.

The discriminant diagrams of Figures 11 and 13 produced consistent data to show a correlation with the volcanic arc ophiolite model of Dilek \& Furnes $(2011,2014)$ (Fig. 13C). Petrotectonic association similarities are also found between the authors' model and the studied region, given the presence of basalt and pillow lava in the Complex and amphibolites with the same origin, but affected by deformation and rebalanced in a metamorphism grade sufficient for the disappearance of the primary structures.

B

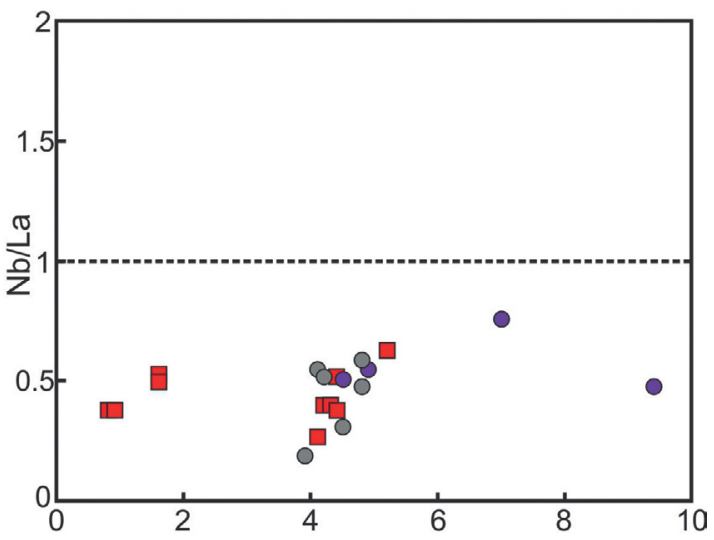

$\square$ North Basalts

South Pillow lavas

Amphibolites

Figure 12. (A) Zr-Zr/Y classification diagram (after Pearce \& Norry 1979); (B) Nb/La diagram; (C) Primitive mantle normalized incompatible trace element spider diagram (after Sun \& McDonough 1989). The light yellow area show the range for subduction zone basalts with its limits based in the average low-K and high-K basalts (Tatsumi \& Eggins 1995). The patterns for oceanic island basalts (OIB) are from Sun \& McDonough (1989). 

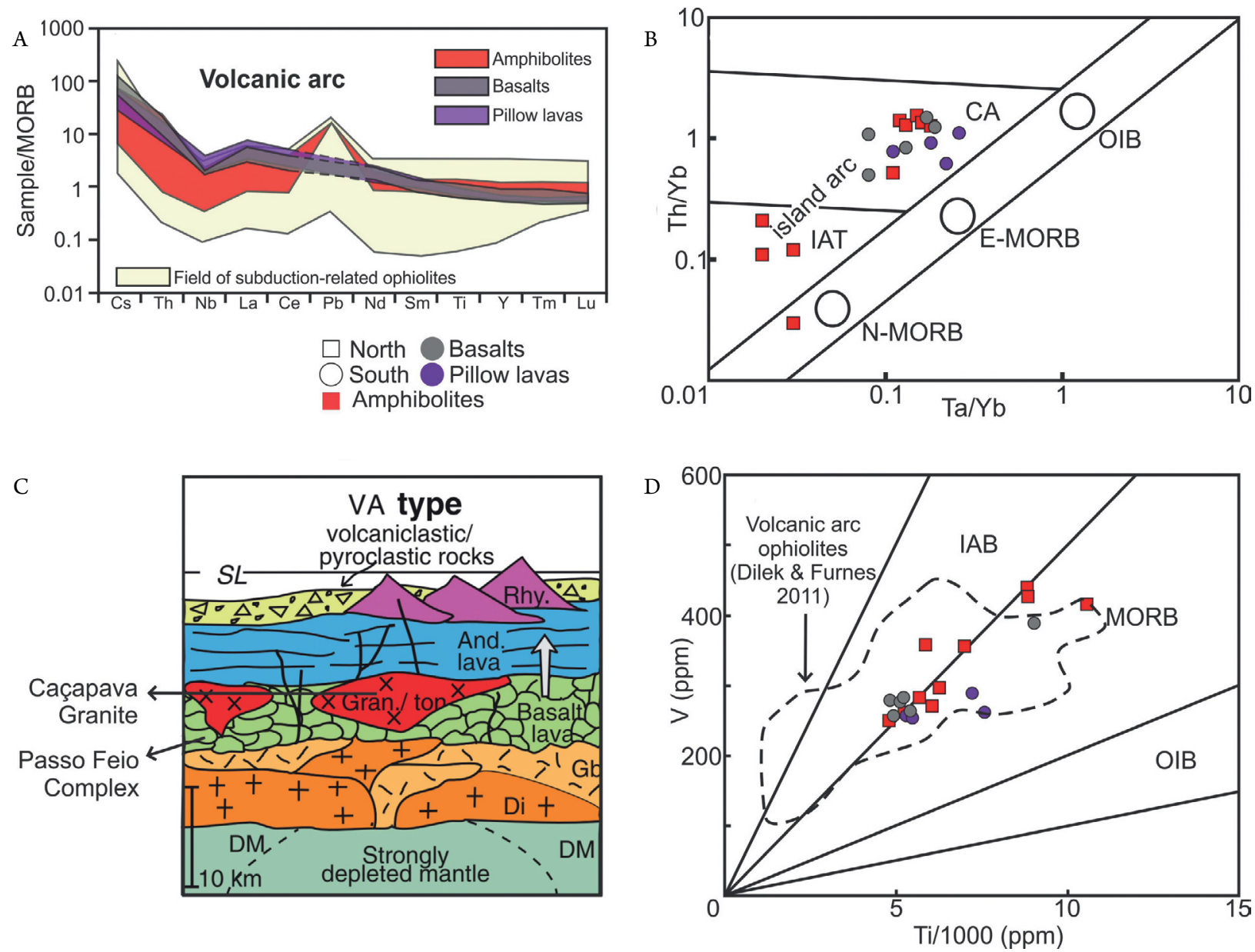

Figure 13. (A) Spider diagram normalized by Dilek \& Furnes (2011) provided values; (B) Th/Yb-Ta/Yb (Pearce 1982) diagram; (C) volcanic arc ophiolites model by Dilek \& Furnes (2011), related to the rocks of the studied region; (D) V-Ti (Shervais 1982) diagram; the dashed field represents the frequency area of volcanic arc type ophiolite samples reclassified by Dilek \& Furnes (2011).

A

Rio de la Plata

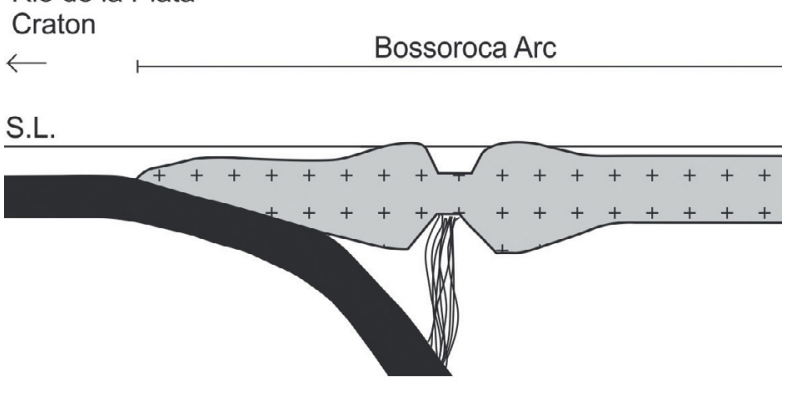

C

WNW

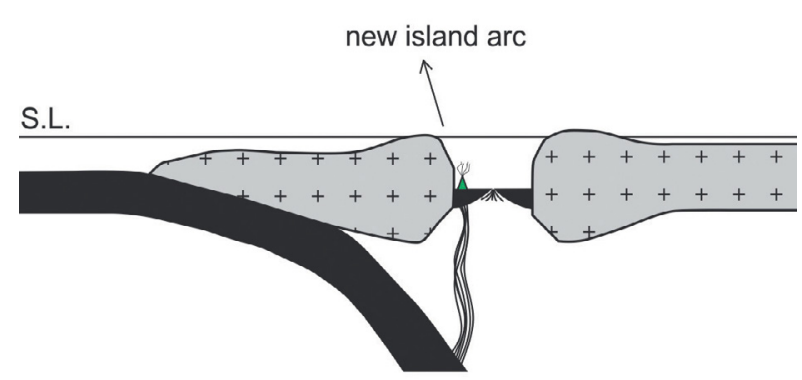

B

$740-730 \mathrm{Ma}$

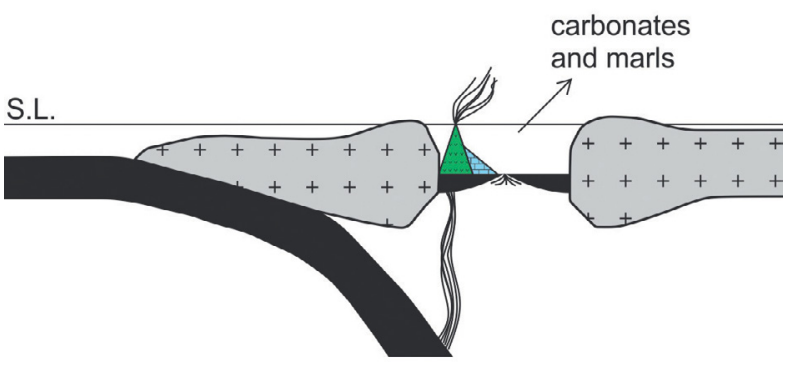

D

$700-560 \mathrm{Ma}$

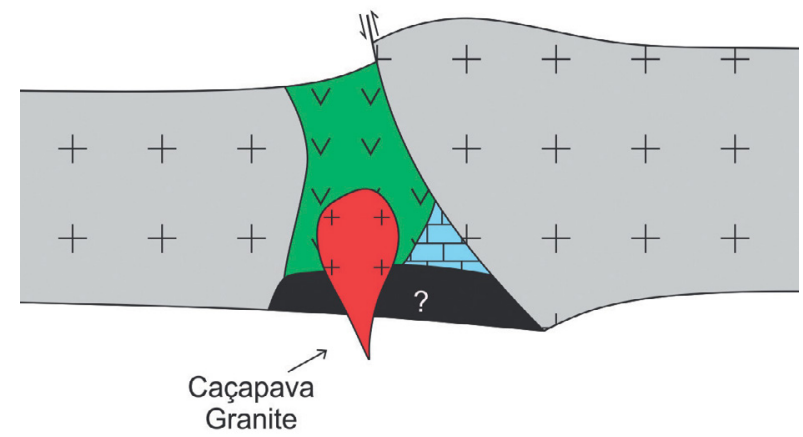

Figure 14. Simplified tectonic evolution model of the Passo Feio Metamorphic Complex rocks. 


\section{Evolution model}

The proposed evolution model is based on the Martinez \& Taylor (2006) model, where there is an opening of a proto-ocean through an island arc rifting (Fig. 14). The proposed model starts with the Bossoroca Arc rifting, dated between 753 and $767 \mathrm{Ma}$ (Machado et al. 1990, Remus et al. 1999, Gubert et al. 2016). The beginning of the arc rifting (and the proto-ocean formation consequently) with formation of continental basalts in this stage is interpreted as approximately $760 \mathrm{Ma}$ (Fig. 14A). In this new oceanic crust, a small island arc was formed, which, with a portion of the oceanic crust, formed the metabasic rocks of PFMC, whose arc was supplied with the Rio de la Plata Craton subducted oceanic crust fused material, the same source that originates the Bossoroca Arc (Fig. 14B). In the newly-formed arc coast, the deposition of carbonate sediments associated with marls and pelites occurred, which generates marbles and pelitic schists, interpreted by the cited authors as deposited in a restricted ocean environment (Goulart et al.2013), in accordance with the proposed model. Goulart et al. (2013) also dated the marbles found in the PFMC through $\mathrm{Sr}^{87} / \mathrm{Sr}^{86}$ and stable isotopes, obtaining a carbonate sediment deposition age between 770 and $730 \mathrm{Ma}$, which serves as an indirect dating of approximately 760 to $740 \mathrm{Ma}$ for the crystallization age of the studied metabasites, given the lack of an absolute crystallization age dating of these rocks (Fig. 14C). From $730 \mathrm{Ma}$, changes in convection cause the beginning of the proto-ocean closure, with a subduction of part of the newly-formed oceanic crust under the studied island arc. The total closure of the proto-ocean caused the collision between the Bossoroca Arc and the Passo Feio terranes, consequently causing the first metamorphic event (with regional character) in the studied rocks with the age of approximately $700 \mathrm{Ma}$ (Remus et al. 1999, 2000), consistent with the approximate age of the amphibolite facies metamorphic peak in the São Gabriel Terrane (Saalmann et al. 2010). Another possibility of the first metamorphic event (M1) is dated from 650 to $590 \mathrm{Ma}$ (Soliani Jr. 1986), which was caused by thrusts (regional metamorphism) in the São Gabriel Terrane in the post-collisional stage of Encantadas Block (Saalmann et al. 2010). The last event (M2) occurred in $562 \mathrm{Ma}$ caused by the late intrusion of the Caçapava Granite at the end of the Brasiliano orogenic cycle, generating the antiformal structure in the PFMC (Fig. 14D).

\section{CONCLUSIONS}

The field survey, combined with the petrographic and geochemical analysis, suggests that the basalt, pillow lava and amphibolite lithologies are all originated from the same protolith, with the mineralogical differences caused by distinct metamorphic grades. The metamorphism in the amphibolites is progressive, reaching low amphibolite facies, without clear retrogressive evidence. The pillow lava and basalt were metamorphosed to prehnite-pumpellyite facies, with the differences in metamorphic facies explained by a shallow crustal level of these rocks.

The basalts, pillow lavas and amphibolites have a predominantly tholeiitic affinity, but in some diagrams, they are transitional to calc-alkaline. The dikes show tholeiitic to alkaline affinity, as shown in the discriminant diagrams. The alkaline affinity of the dikes is reinforced by the kaersutite presence and $\mathrm{Ti}, \mathrm{Cr}$, and $\mathrm{Al}$-rich pyroxenes.

The discriminant chemical composition diagrams suggest a contaminated continental basalt formation, followed by an island arc for the rock formation environment, compatible with the volcanic arc ophiolites from the model of Dilek \& Furnes (2011). The Passo Feio Complex continental basalts are formed in the rifting stage of the Bossoroca Arc, while island arc rocks are formed in a restricted ocean generated in the interior of Bossoroca Arc, with a deposition of carbonates and marls on its border, metamorphosed after the closure of the ocean and intruded by the Caçapava Granite. The Hilário Formation dikes do not have any relationship with the PFMC metabasites.

\section{ARTICLE INFORMATION}

Manuscript ID: 20180039. Received on: 04/04/2018. Approved on: 01/22/2019.

A.V.B. made the research, wrote the text and the models for the metamorphic evolution, made the figures and tables, the microprobe analysis and some geochemistry analysis; M. V. D. R. provided orientation, improved the manuscript with corrections and suggestions for figures, tables and text and wrote some additions for the text; N. D. provided and helped with the X-ray fluorescence and made corrections and contributions to the text; R. R. contributed with REE and some geochemistry analysis and with knowledge of the studied region. Competing interests: The authors declare no competing interests.

\section{REFERENCES}

Almeida F.F.M. 1977. O Cráton do São Francisco. Revista Brasileira de Geociências, 7(4):349-363.

Arena K.R., Hartmann L.A., Lana C. 2017. Tonian emplacement of ophiolites in the southern Brasiliano Orogen delimited by U-Pb-Hf isotopes of zircon from metasomatites. Gondwana Research, 49:296-332. http:// dx.doi.org/10.1016/j.gr.2017.05.018

Babinski M., Chemale Jr. F., Hartmann L.A., Van Schmus W.R., Silva L.C. 1996. Juvenile accretion at 750-700 Ma in southern Brazil. Geology, 24(5):439-442. https://doi.org/10.1130/0091-7613(1996)024\%3C0439:JAAMIS\%3E2.3.CO;2
Bitencourt M.F. 1983. Geologia, Petrologia e Estrutura dos Metamorfitos da Região de Caçapava do Sul, RS. MS Dissertation, Universidade Federal do Rio Grande do Sul, Porto Alegre, 161 p.

Bitencourt M.F. \& Hartmann L.A. 1984a. Geoquímica das rochas anfibolíticas da região de Caçapava do Sul, Parte I: Caracterização geológica e petrográfica, elementos maiores e menores. In: Congresso Brasileiro de Geologia, 33. Anais..., 9:4253-4265.

Bitencourt M.F. \& Hartmann L.A. 1984b. Reconhecimento geoquímico dos xistos magnesianos da região do Passo Feio, Caçapava do SuI - RS. In: Congresso Brasileiro de Geologia, 33. Anais..., 6:2607-2614. 
Brown G.C. \& Musset A.E. 1993. The Inaccessible Earth, an Integrated View of Its Structure and Composition. Chapman and Hal, London.

Camozzato E., Klein C., Iglesias C.M.F. 2014. Geological map of Bagé, Rio Grande do Sul, Porto Alegre. Brazil Geological Survey SH.21-Z-D-III. Scale 1:100.000. Brazil.

Caritat P., Hutcheon I., Walshe J.L. 1993. Chlorite geothermometry: A review. Clays \& Clay Miner, 41(2):219-239.

Chaves C.D.R., Remus M.V.D., Rizzardo R.S. 2010. Metabasitos do Arroio Mudador - Caçapava do Sul/RS. In: Salão de Iniciação Científica, 22., Porto Alegre. Anais... Porto Alegre: UFRGS

Chemale Jr. F. 2000. Evolução Geológica do Escudo Sul Rio Grandense. In: Holz M., De Ros L.F. (Eds.). Geologia do Rio Grande do Sul. Porto Alegre: Editora UFRGS, p. 13-52.

Chemale Jr. F., Hartmann L.A., da Silva L.C. 1995. Stratigraphy and tectonism of Precambrian to early Paleozoic units in southern Brazil and Uruguay. Acta Geológica Leopoldensia, 42:5-117.

Deer W.A., Howie R.A., Zussman J. 1992. An introduction to rock forming minerals. Harlow: Longman. 696 p.

Dilek Y. \& Furnes H. 2011. Ophiolite genesis and global tectonics: Geochemical and tectonic fingerprinting of ancient oceanic lithosphere. Geological Society of America Bulletin, 123(3-4):387-411. https://doi. org/10.1130/B30446.1

Dilek Y. \& Furnes H. 2014. Ophiolites and their origins. Elements, 10(2):93100. https://doi.org/10.2113/gselements.10.2.93

Faleiros F.M., Ferrari V.C., Costa V.S., Campanha G.A.C. 2011. Geoquímica e petrogênese de metabasitos do Grupo Votuverava (Terreno Apiaí, Cinturão Ribeira Meridional): Evidências de uma bacia retroarco Calimiana. Geologia USP, Série Científica, 11(2):135-155. https://doi.org/10.5327/ Z1519-874X2011000200008

Floyd P.A. \& Winchester J.A. 1975. Magma type and tectonic setting discrimination using immobile elements. Earth and Planetary Science Letters, 27(2):211-218. https://doi.org/10.1016/0012-821X(75)90031-X

Floyd P.A., Göncüoğlu M.C., Winchester J.A., Yaliniz M.K. 2000. Geochemical character and tectonic environment of Neotethyan ophiolitic fragments and metabasites in the Central Anatolian Crystalline Complex, Turkey. Geological Society, London, Special Publications, 173:183-202. https://doi.org/10.1144/GSL.SP.2000.173.01.09

Fragoso Cesar A.R.S. 1991. Tectônica de placas no Ciclo Brasiliano: as orogenias dos Cinturões Dom Feliciano e Ribeira no Rio Grande do Sul. PhD Thesis, Instituto de Geociências, Universidade de São Paulo, São Paulo, 362 p.

Franz G. \& Liebscher A. 2004. Physical and chemical properties of the epidote minerals - An introduction. In: Liebscher A. \& Franz G. (Eds.). Epidotes. America: Mineralogical Society of America, p. 1-81.

Goulart R., Remus M.V.D., Reis R.S. 2013. Composição isotópica de Sr, C e O e geoquímica de ETRs das rochas carbonáticas do Bloco São Gabriel, Rio Grande do Sul. Pesquisas em Geociências, 40(1):75-97.

Grapes R.H. \& Hoskin P.W.O. 2004. Epidote group minerals in lowmedium pressure metamorphic terranes. In: Liebscher A. \& Franz G. (Eds.). Epidotes. America: Mineralogical Society of America, p. 301-345.

Gubert M.L., Philipp R.P., Basei M.A.S. 2016. The Bossoroca Complex, São Gabriel Terrane, Dom Feliciano Belt, southernmost Brazil: U-Pb geochronology and tectonic implications for the neoproterozoic São Gabriel Arc. Journal of South American Earth Sciences, 70:1-17. http:// dx.doi.org/10.1016/j.jsames.2016.04.006

Hartmann L.A., Chemale Jr. F., Philipp R.P. 2007. Evolução Geotectônica do Rio Grande do Sul no Pré-Cambriano. In: Iannuzz R., Frantz J.C. (Eds.). 50 anos de Geologia. Porto Alegre: Instituto de Geociências, p. 97-123.

Hartmann L.A., Remus M.V.D. 2000. Origem e evolução das rochas ultramáficas do Rio Grande do Sul desde o Arqueano até o Cambriano. In: Holz M., De Ros L.F. (Eds.). Geologia do Rio Grande do Sul. Porto Alegre: CIGO/Universidade Federal do Rio Grande do Sul, p. 53-78.

Jost H. 1966. Complexos básico-ultrabásicos do Alto Rio Vacacaí, São Gabriel, Rio Grande do Sul. Boletim da Escola de Geologia da Universidade Federal do Rio Grande do Sul, 1(2):55-61.
Jost H. \& Hartmann L.A. 1984. Província Mantiqueira - Setor Meridional. In: Almeida F.F. \& Hasui Y. (Eds.). O Pré-Cambriano do Brasil. São Paulo.

Jowett E.C. 1991. Fitting iron and magnesium into the hydrotherma chlorite geothermometer. In: GAC/MAC/SEG Joint Annual Meeting. Anais..., A62.

Laux J.H., Bongiolo E.M., Klein C., Iglesias C.M.F. 2012. Geological map of Lagoa da Meia Lua, Rio Grande do Sul, Porto Alegre. Brazil Geological Survey SH.21-Z-B-VI, Scale 1:100.000. Brazil: Brazil Geological Survey.

Le Bas M.J. 1962. The role of aluminium in igneous clinopyroxenes with relation to their parentage. American Journal of Science, 260(4):267-288. http://dx.doi.org/10.2475/ajs.260.4.267

Le Bas M.J., Le Maitre R.W., Streckeisen A., Zanettin B. 1986. A chemical classification of volcanic-rocks based on the Total Alkali Silica Diagram. Journal of Petrology, 27(3):745-750. https://doi.org/10.1093/ petrology/27.3.745

Leake B.E., Woolley A.R., Arps C.E.S., Birch W.D., Gilbert M.C., Grice J.D., Hawthorne F.C., Kato A., Kisch H.J., Krivovichev V.G., Linthout K., Laird J., Mandarino J.A. Maresch W.V., Nickel E.H., Rock N.M.S., Schumacher J.C., Smith D.C., Stephenson N.C.N., Ungaretti L., Whittaker E.J.W., Youzhi G. 1997. Nomenclature of amphiboles: Report of the subcommittee on amphiboles of the International Mineralogical Association, commission on new minerals and mineral names. The Canadian Mineralogist, 35 (1):219-246.

Leterrier J., Maury R.C., Thonon P., Girard D., Marchal M. 1982. Clinopyroxene composition as a method of identification of the magmatic affinities of paleo-volcanic series. Earth and Planetary Science Letters, 59(1):139-154. https://doi.org/10.1016/0012-821X(82)90122-4

Lopes C.G., Pimentel M.M., Philipp R.P., Gruber L., Armstrong R., Junges S. 2015. Provenance of the Passo Feio complex, Dom Feliciano Belt: Implications for the age of supracrustal rocks of the Sao Gabriel Arc, southern Brazil. Journal of South American Earth Sciences, 58:9-17. https:// doi.org/10.1016/j.jsames.2014.11.004

Macedo P.M., Beckel J., Santos E.L., Chaban N., Gonzales Filho F. 1978. Ocorrência de "pillow-lavas" no Arroio Mudador município de Caçapava do Sul - RS. In: Congresso Brasileiro de Geologia, 30., Recife. Anais... Recife: SBG, 3:1269-1278.

Machado N., Koppe J.C., Hartmann L.A. 1990. A Late Proterozoic $\mathrm{U}-\mathrm{Pb}$ age for the Bossoroca Belt, Rio Grande do Sul, Brazil. Journa of South American Earth Sciences, 3(2-3):87-90. https://doi. org/10.1016/0895-9811(90)90021-R

Maniesi V. \& Oliveira M.A.F. 2000. Petrogênese dos metabasitos com afinidades dos toleítos de fundo oceânico das regiões de Adrianópolis e Campo Largo/PR. Revista Brasileira de Geociências, 30(4):607-614.

Martinez F. \& Taylor B. 2006. Modes of crustal accretion in back-arc basins: Inferences from the Lau Basin. In: Christie D.M., Fisher C.R., Lee S.M., Givens S. (Eds.). Back-Arc Spreading Systems: Geological, Biological, Chemical, and Physical Interactions. Washington, D.C.: American Geophysical Union, $303 \mathrm{p}$.

Meschede M. 1986. A method of discriminating between different types of mid-ocean ridge basalts and continental tholeiites with the Nb-Zr-Y diagram. Chemical Geology, 56(3-4):207-218. https://doi. org/10.1016/0009-2541(86)90004-5

Morimoto N. 1988. Nomenclature of pyroxenes. Mineralogy and Petrology, 39(1):55-76. https://doi.org/10.1007/BF01226262

Morris P.A. 1988. Petrogenesis of Fore-arc Metabasites from the Paleozoic of New England, Eastern Australia. Mineralogy and Petrology, 38(1):1-16. https://doi.org/10.1007/BF01162478

Mullen E.D. 1983. $\mathrm{MnO} / \mathrm{TiO}_{2} / \mathrm{P}_{2} \mathrm{O}_{5}$ : a minor element discriminant for basaltic rocks of oceanic environments and its implications for petrogenesis. Earth and Planetary Science Letters, 62(1):53-62. https://doi. org/10.1016/0012-821X(83)90070-5

Pearce J.A. 1982. Trace element characteristics of lavas from destructive plate boundaries. In: Thrope R.S. (Ed.). Andesites: Orogenic Andesites and Related Rocks. Chichester: J. Wiley and Sons, p. 525-548.

Pearce J.A. \& Cann J.R. 1973. Tectonic setting of basic volcanic rocks determined using trace element analyses. Earth and Planetary Science Letters, 19(2):290-300. https://doi.org/10.1016/0012-821X(73)90129-5 
Pearce J.A. \& Norry M.J. 1979. Petrogenetic implications of Ti, Zr, Y and $\mathrm{Nb}$ variations in volcanic rocks. Contributions to Mineralogy and Petrology, 69(1):33-47. https://doi.org/10.1007/BF00375192

Rapela C.W., Pankhurst R.J., Casquet C., Fanning C.M., Baldo E.G., González-Casado J.M., Galindo C., Dahlquist J. 2007. The Río de la Plata craton and the assembly of SW Gondwana. Earth-Science Reviews, 83(1):4982. https://doi.org/10.1016/j.earscirev.2007.03.004

Remus M.V.D., Hartmann L.A., Formoso M.L.L. 1993. Os padrões de Elementos Terras Raras (ETR) e a afinidade geoquímica komatítica dos xistos magnesianos e rochas associadas do Complexo Cambaizinho, São Gabriel/RS. Revista Brasileira de Geociências, 23(4):370-387.

Remus M.V.D., Hartmann L.A., McNaughton N.J., Groves D.I., Fletcher I.R. 2000. The link between hydrothermal epigenetic copper mineralization and the Caçapava Granite of the Brasiliano Cycle in southern Brazil. Journal of South American Earth Sciences, 13(3):191-216. https://doi.org/10.1016/ S0895-9811(00)00017-1

Remus M.V.D., Hartmann L.A., Ribeiro M. 1991. Nota sobre a geologia dos metamorfitos de pressão intermediária e granitoides associados da região de Pinheiro Machado, RS. Acta Geologica Leopoldensia, 14(34):175-189.

Remus M.V.D., McNaughton N.J., Hartmann L.A., Koppe J.C., Fletcher I.R., Groves D.I., Pinto V.M. 1999. Gold in the Neoproterozoic juvenile Bossoroca Volcanic Arc of southernmost Brazil: isotopic constraints o timing and sources. Journal of South American Earth Sciences, 12(4):349366. http://dx.doi.org/10.1016/S0895-9811(99)00026-7

Ribeiro M. 1970. Geologia da Folha Bom Jardim: Rio Grande do Sul - Brasil. Brasília: Divisão de Geologia e Mineralogia, 142 p.

Ribeiro M., Bocchi P.R., Figueiredo F.P.M., Tessari R.I. 1966. Geologia da Quadrícula de Caçapava do Sul, RS. Rio de Janeiro: DNPM/DFPM, $232 \mathrm{p}$.

Saalmann K., Gerdes A., Laheye Y., Hartmann L.A., Remus M.V.D., Läufer A. 2010. Multiple accretion at the eastern margin of the Rio de la Plata craton: the prolonged Brasiliano orogeny in southernmost Brazil. International Journal of Earth Sciences, 100(2):355-378. http://dx.doi. org/10.1007/s00531-010-0564-8

Saalmann K., Hartmann L.A., Remus M.V.D., Koester E., Conceição R.V. 2005. Sm-Nd isotope geochemistry of metamorphic volcano-sedimentary successions in the Sao Gabriel Block, southernmost Brazil: Evidence for the existence of juvenile Neoproterozoic oceanic crust to the east of the Rio de la Plata craton. Precambrian Research, 136(2):159-175. http://dx.doi. org/10.1016/j.precamres.2004.10.006

Saalmann K., Remus M.V.D., Hartmann L.A. 2006. Tectonic evolution of the Neoproterozoic São Gabriel Block, southern Brazil - constraints on Brasiliano orogenic evolution of the Rio de la Plata cratonic margin. Journal of South American Earth Sciences, 21(3):204-227. http://dx.doi. org/10.1016/j.jsames.2006.05.003

Shervais J.W. 1982. Ti-V plots and the petrogenesis of modern and ophiolitic lavas. Earth and Planetary Science Letters, 59(1):101-118. https://doi. org/10.1016/0012-821X(82)90120-0
Soliani Jr. E. 1986. Os dados geocronológicos do Escudo Sul-Rio-Grandense e suas implicações de ordem geotectônica. PhD Thesis, Instituto de Geociências, Universidade de São Paulo, São Paulo, 425 p.

Sun S.S., McDonough W.F. 1989. Chemical and isotopic systematics of oceanic basalts: implications for mantle composition and processes. In: Saunders A.D., Norry M.J. (Eds.). Magmatism in the ocean basins. Geological Society, London, Special Publications, 42:313-346.

Szubert C.E., Kirchner C.A., Grazia C.A., Andriotti J. L.S., Shintaku I., Kern A.M.S., Zambrowski A.J., Goulart V., Castro V.H.S., Fuller O., Orlandi Filho V., Giffoni L.E., Gonçalves G.N.D. 1977. Projeto Cobre nos corpos básico-ultrabásicos e efusivas do Rio Grande do Sul. Relatório Final, 2a fase convênio CPRM-DNPM. Porto Alegre: CPRM-DNPM, 113 p.

Tatsumi Y., Eggins S.M. 1995. Subduction Zone Magmatism. Cambridge: Blackwell Science, $211 \mathrm{p}$

Tindle A. 2010. Chlorite formula unit calculator and variety namer. Available at: <http://www.open.ac.uk/earth-research/tindle/AGT/AGT_ Home_2010/Microprobe-2.html>. Accessed on: Feb. 20, 2018.

Toniolo J.A., Gil C.A.A., Sander A. 2007. Metalogenia das Bacias Neoproterozóicas-Eopaleozóicas do Sul do Brasil: Bacia do Camaquã. Porto Alegre: CPRM, $154 \mathrm{p}$.

Winchester J.A. \& Floyd P.A. 1976. Geochemical magma type discrimination: application to altered and metamorphosed basic igneous rocks. Earth and Planetary Science Letters, 28(3):459-469. https://doi. org/10.1016/0012-821X(76)90207-7

Winchester J.A. \& Floyd P.A. 1977. Geochemical discrimination of different magmaseriesandtheirdifferentiationproductsusingimmobileelements. Chemical Geology, 20:325-343. https://doi.org/10.1016/0009-2541(77)90057-2

Winter J.D. 2014. Principles of Igneous and Metamorphic Petrology. London: Pearson Education Limited, 702p.

Wood D.A., Joron J.-L., Treuil M. 1979. A re-appraisal of the use of trace elements to classify and discriminate between magma series erupted in different tectonic settings. Earth and Planetary Science Letters, 45(2):326336. https://doi.org/10.1016/0012-821X(79)90133-X

Xia L.Q. 2014. The geochemical criteria to distinguish continental basalts from arc related ones. Earth-Science Reviews, 139:195-212. http://dx.doi. org/10.1016\%2Fj.earscirev.2014.09.006

Xia L.Q. Xia Z.C., Xu X.Y., Li X.M., Ma Z.P. 2008. Relative contributions of crust and mantle to the generation of the Tianshan Carboniferous riftrelated basic lavas, northwestern China. Journal of Asian Earth Sciences, 31(4-6):357-378. https://doi.org/10.1016/j.jseaes.2007.07.002

Xu D., Xia B., Bakun-Czubarow N., Bachlinski R., Li P., Chen G., Chen T. 2008. Geochemistry and Sr-Nd isotope systematic of metabasites in the Tunchang area, Hainan Island, South China: implications for petrogenesis and tectonic setting. Mineralogy and Petrology, 92(3-4):361-391. https:// doi.org/10.1007/s00710-007-0198-0

Zane A. \& Weiss Z. 1998. A procedure for classifying rock-forming chlorites based on microprobe data. Rendiconti Lincei Scienze Fisiche e Naturali Serie, 9(1):51-56. http://dx.doi.org/10.1007/BF02904455 